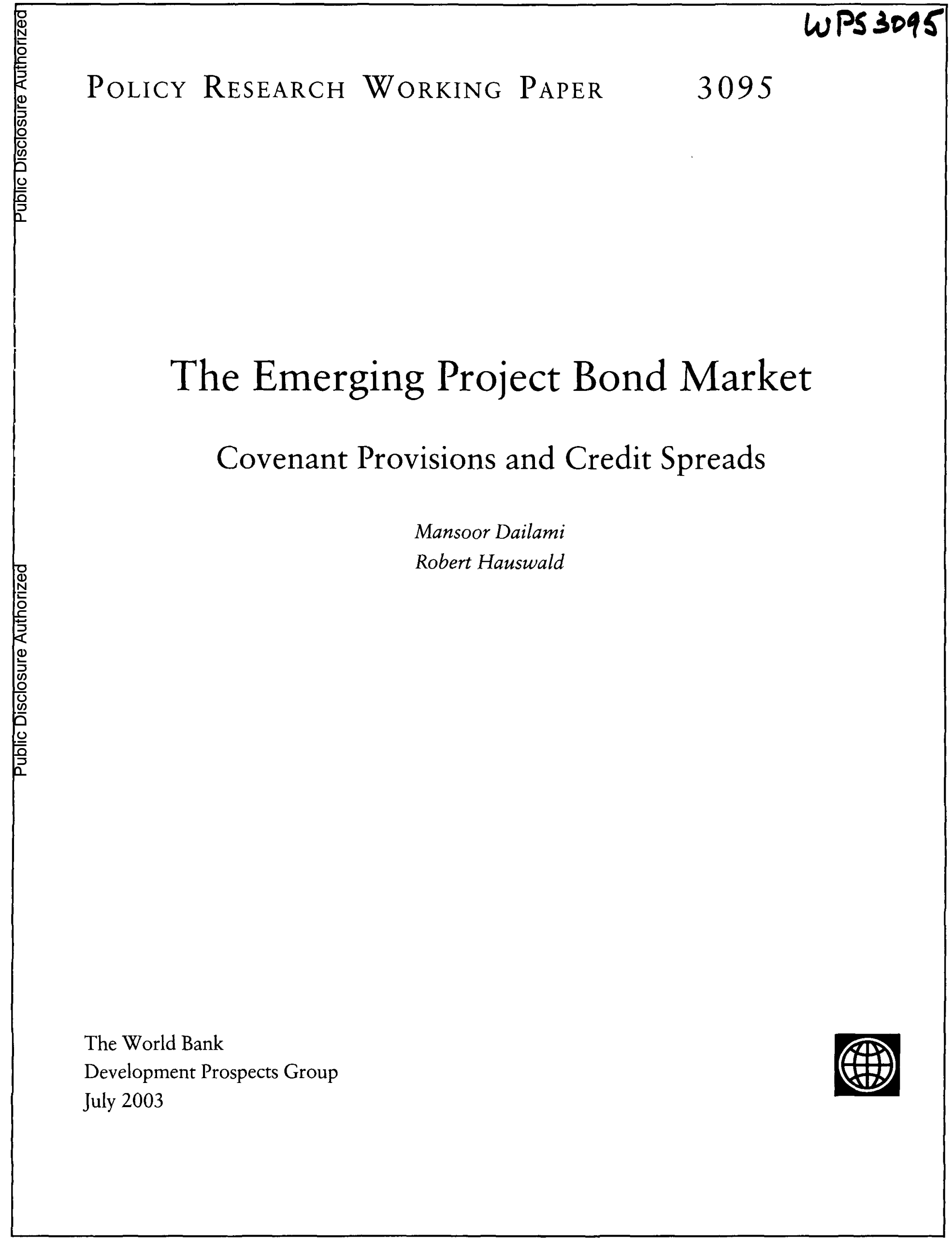


Policy Research Working Paper 3095

\section{Abstract}

The emergence in the 1990s of a nascent project bond market to fund long-term infrastructure projects in developing countries merits attention. Dailami and Hauswald compile $\therefore$ tailed information on a sample of 105 bonds issued between January 1993 and March 2002 for financing infra.r-rinrtiz- projects in developing countries, document their contractual covenants, and analyze their pricing determinants. They find that on average, project bonds are issued at approximately 300 basis points above U.S. Treasury securities, have a surprisingly high issue size of US $\$ 278$ million, a maturity of slightly under 12 years, and are rated slightly below investment grade. In terms of geographic origin, projects in Asia and Latin America have issued more bonds than those located in other regions.
Much of the recent work relating to the role of contractual covenants to the determination of bond prices has focused on the U.S. corporate bond market with its unique bankruptcy code (Chapter 11) and well developed legal framework, recognizing the bond contract as the sole instrument of defining the rights and duties of various parties. In circumstances in which the underpinning legal and institutional frameworks governing contract formation and enforcement are not well developed, the link between bond pricing and legal framework becomes important. This finding is confirmed by the authors' econometric analysis of project bond pricing model. So, investors take into account the quality of the host country's legal framework and reward projects located in countries that adhere to the rule of law with tighter credit spreads and lower funding costs.

This paper-a product of the Development Prospects Group-is part of a larger effort in the group to promote a healthy flow of investment capital to developing countries' infrastructure. Copies of the paper are available free from the World Bank, 1818 H Street NW, Washington, DC 20433. Please contact Sarah Crow, room MC2-358, telephone 202-473-0763, fax 202-522-2578, email address scrow@worldbank.org. Policy Research Working Papers are also posted on the Web at http://econ.worldbank.org. The authors may be contacted at mdailami@worldbank.org or hauswald@american.edu. July 2003. (35 pages) 
World Bank Policy Research Working Paper

\title{
The Emerging Project Bond Market: Covenant Provisions and Credit Spreads
}

\author{
Mansoor Dailami \\ Development Prospects Group \\ World Bank \\ Washington, DC 20433 \\ and \\ Robert Hauswald \\ Kogod School of Business \\ American University \\ Washington, DC 20016-8044
}





\begin{abstract}
The emergence in the 1990s of a nascent project bond market to fund long-term infrastructure projects in developing countries merits attention. This paper complies detail information on a sample of 105 bonds issued between January 1993 and March 2002 for financing infrastructure projects in developing, documents their contractual covenants, and analyses their pricing determinants. It is found that on average, project bonds are issued at approximately 300 basis points above US Treasury securities, have a surprisingly high issue size of US\$278 million, a maturity of slightly under 12 years and are rated slightly below investment grade.In terms of geographic origin, projects in Latin America and Asia have issued more bonds than those located in other regions.

Much of the recent work relating the role of contractual covenants to the determination of bond prices has focused on the US corporate bond market with unique bankruptcy code (Chapter 11) and well developed legal framework, recognizing the bond contract as the sole instrument of defining the rights and duties of various parties. In circumstances in which the underpinning legal and institutional frameworks governing contract formation and enforcement are not well developed, the link between bond pricing and legal framework becomes important, a finding confirmed by our econometric analysis of project bond pricing model. Hence, investors take into account the quality of host country legal framework and reward projects located in host countries that adhere to the rule of law with tighter credit spreads and lower funding costs
\end{abstract}




\section{Emerging Project Bond Market: Covenant Provisions and Credit Spreads}

\section{Introduction}

The emergence in the 1990s of a nascent project bond market to fund long-term infrastructure projects in developing countries, such as electric power plants, roads, ports, airports, telecommunications networks, and water and waste water facilities, merits attention for several reasons. First, they highlight the attractiveness of such investment opportunities that are traditionally the preserve of the public sector for private sources of capital. Second, project bonds are potentially a major source of long-term private debt capital linked directly to economic growth and competitiveness. Third, they are a new asset class in the emerging market debt spectrum, offering asset diversification and investment opportunities particularly to institutional investors, such as insurance companies and pension funds whose long-term liabilities match the long-term tenor of project bonds. Finally, they mirror the shift in the pattern of capital flows from bank loans to publicly issued bonds. ${ }^{1}$

Although the volume of capital raised through international project bonds remains relatively small, the market has gained maturity in a very short time span, delivering a series of high profile transactions such as US\$1.2 billion issued by the Ras Laffan Liquefied Natural Gas project in Qatar, US\$1 billion issued by the Petrozuata heavy oil project in Venezuela, ${ }^{2}$ and US\$125 million issued by the Quezon power project in the Philippines. Today, the market encompasses a broad range of project types, issue sizes, seniorities, and maturities. The total issuance volume worldwide has been on the order of US\$25 billion (2000-2001) of which about one third is attributed to bonds issued by projects located in developing countries. The market's long-term prospects, driven by the massive infrastructure needs in developing countries, look very promising.

For more on global capital flows see the World Bank Global Development Finance 2003; capital flows to infrastructure development are discussed in Dailami and Leipziger (1998).

2 See Dailami and Hauswald (2001) for an in-depth analysis of the Ras Laffan project and the role that international bond finance played in its successful design and completion. Esty (1999) describes the Petrozuata project, a heavycrude oil project in Venezuela that provides a complementary example to Dailami and Hauswald (2001) and shows how international bond finance could be accessed despite complex legal, contractual, and political risks. 
Projet Bond, Emerging Sovereign, and 10Y US Treasury Yields

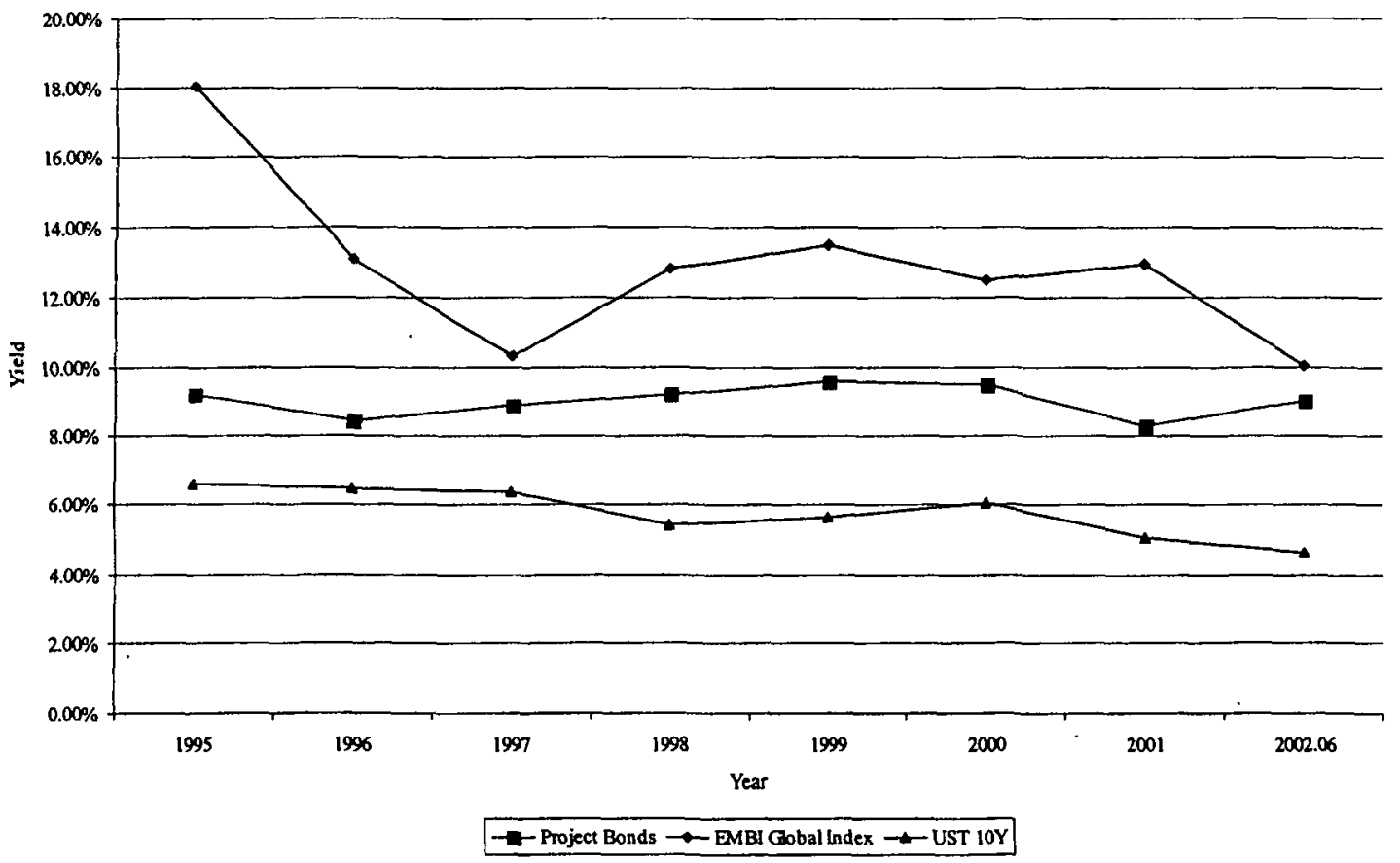

Note: All yields are yields to maturity; the Emerging Market Sovereign yields are from the JP Morgan EMBI Global index.

This note examines the emergence and growth of this market as a new asset class within the emerging-market debt spectrum. The evolution of project bonds is benchmarked against the more established fixed income markets in terms of pricing (at-issue spreads) as well as legal structures and covenant provisions. An examination of a sample of such bonds issued between January 1993 and March 2002 reveals that project indentures contain the standard covenant provisions aimed at mitigating conflicts of interest between bondholders and shareholders that manifest themselves through asset substitution, dividend policies, claim dilution, and under investment (Warner and Smith 1997). In addition, project-bond indentures contain clauses that serve as commitment and incentive devices for host governments and other contracting parties to the project.

In terms of borrowing cost, we find that project bonds are priced at a considerable markup (average $300 \mathrm{bps}$ spread) over comparable US Treasury securities, but with a high degree of variation across bonds that depends on project-specific characteristics, bond features, and the quality of host-countries' legal institutions in determining investor rights and the degree of their protection. However, the preceding graph also shows that project bonds, despite wide variations in number of 
issues and their size, have consistently carried issue yields below comparable emerging-market sovereign yields (JP Morgan's EMBI Global Index). Two factors are at work. First and foremost, only the most creditworthy projects can tap the markets and, therefore, often carry a comparatively higher credit rating. Second, issuers take particular care in designing their projects' organizational, legal, and financial structure when they wish to fund them in public debt markets. Taken together, both forces suggest that the at-issue spread evolution depicted above is largely due to selfselection by borrowers: only high-quality and well-designed projects and their bonds come to market which then carry credit ratings and issue-yields below a much larger and diverse group of sovereign borrowers.

This note is organized as follows. We next discuss the key economic and financial issues in the international project-bond market before turning to the legal design of typical project bonds in Section III. Section IV summarizes our analysis of credit-spread determinants that highlight the importance of the ambient institutional development, and Section V concludes.

\section{Key Characteristics of the Project-Bond Market}

Access to the international bond markets by infrastructure projects in emerging economies is a relatively new phenomenon, borne of the economic reforms, market liberalization, and financial innovations in the early 1990s. The world-wide move towards private participation in infrastructure (PPI) schemes that gained momentum in the early 1990s brought about fundamental changes in the traditional fiscal financing of infrastructure facilities. ${ }^{3}$ It also ushered in structural changes in the way in which infrastructure was operated and managed as a pre-requisite for successful private funding or projects. For instance, the development of structured credit techniques, most prominently limited recourse project financing methods, along with various risk sharing and hedge devices (multilateral and export credit agencies (ECA) guarantees, private political risk insurance), were instrumental in containing projects' credit risk sufficiently to make them of interest to bond investors. At the same time, privatization, market liberalization, and regulatory reforms created an economic environment that could provide private investors with return potentials that could justify the considerable risks associated with debt investments in emerging market infrastructure.

${ }^{3}$ Brealey, Cooper and Habib (1996) contains an excellent survey of the economic issues involved in project finance. 
An important factor contributing to investor interest has been the creative design of the debt securities' legal structures such as indenture, trust structure, selective guarantees, and covenant provisions to mitigate risks and provide contractual protection to bond holders. Financial economists have long recognized the adverse incentives that debt finance provides to shareholders and managers and the agency costs that those entail. Smith and Warner (1979) discuss how bond covenants typically attempt to address various conflicts of interest between different classes of claim holders while Green (1984) and John (1987) formally analyze the incentives that leverage creates for shareholders (project sponsors) to enhance their own returns by shifting risk to debtholders through project attribute selection.

While most project bonds are corporate bonds, the reverse is not true. There are subtle financial, economic, and analytical differences between the two segments that merit further attention in the context of an institutional analysis of the market. The dissimilarities primarily stem from the underlying economics of the borrower. In the case of a project, the issuer raises funds to finance a single indivisible large-scale capital investment project whose cash flows are the sole source to meet financial obligations and to provide returns to investors. ${ }^{4}$ In the case of a typical corporate borrower, the security is typically issued against the firm's general credit and the underlying assets consist of multiple sources of cash flows. Hence, typical corporate bonds are secured by all the firm's various assets and cash flows that offer in themselves risk diversification and an important cross-insurance mechanism. If a certain set of cash flows becomes unavailable for debt service, firms typically have other sources of cash that might tide the issuer over the liquidity crisis.

No such cross-insurance exists in the case of project bonds: the moment the single source of cash flows ceases to exist, the issuer experiences a liquidity crisis that might force it to default on its bonds. In addition, projects suffer from asset-specificity (location and/or use of the assets), often ill-defined or ill-enforced property rights, and bilateral monopoly settings (dominant output buyer) that render them vulnerable to opportunistic behavior and unilateral contract renegotiation. Indeed, such opportunistic behavior coupled with shortcomings in the ambient legal institutions is often at the root of project's economic distress and, ultimately, financial distress.

${ }^{4}$ On the other hand, the single source of cash flows and limited number of contractual relations facilitated the analysis of project bonds. 
These often overlooked, but crucial differences between project and general corporate bonds subtly affect investors' risk perceptions, the pricing of the bonds, and their legal structure. In particular, investors do not tend to view the underlying assets as "true security" even if they are pledged as such, but take into account and price factors, such as the creditworthiness of off-takers, third-party guarantees, the legal and institutional environment, and, ultimately, the quality of the cash flows. Put differently, investors in project bonds are much more cash-flow quality oriented than buyers of typical corporate bonds and tend to price factors that determine the underlying economics of the project. However, since projects and their securities demand much more careful analysis of the issuer's economic and legal structures, buyers of project bonds are mostly sophisticated institutional investors that have the requisite analytical expertise, rather than retail investors.

In order to document current trends and best practices in the international project-bond market, we collected a representative sample of 105 emerging market project bonds issued between January 1993 and March 2002. The issue information that we cross-checked with other data sources comes mainly from Bloomberg and Interactive Data Corporation (IDC). If the spread-atissue over comparable US Treasury securities is not provided, we calculate it from the bond's issue yield and the yield of an interpolated maturity-matched Treasury security. Bond prospectuses and ratings studies from Moody's and Standard \& Poors provide the necessary information on the projects' contractual structure, its off-take (output supply) agreement, the bond covenant, and legal terms and conditions.

Table 6 in the Appendix lists all our bonds by country and provides specific information on the terms and structure of each issue. Our sample reflects a broad cross-section of countries, project types, and sectors. International project bonds differ widely in their issue size, maturity, issue spread, host country sovereign spread, underlying project structure, legal characteristics, and covenants. Issue size ranges from US\$23 million (LIGHT, Brazil) to US\$1 billion (KowloonCanton Railway Corp., China, and Pemex Mexico) their rating by Moody's from AAA to B2, their maturity from less than three years (Transportadora de gas del Sur, Argentina) to 100 years (albeit callable after 30 years), and the yield at issue over US Treasuries from 10 basis points for a convertible bond by a Chinese issuer to 802 basis points for a South-African one. The following table summarizes typical characteristics of project bonds on the basis of our sample. 


\begin{tabular}{lrrrr}
\hline \multicolumn{1}{c}{ Characteristics } & Mean & Std. Dev. & Min & Max \\
\hline Spread over US Treasuries & & & & \\
Amount & 297.80 & 173.81 & 10 & 802.17 \\
Maturity (years) & 278.07 & 201.62 & 23 & 1000 \\
Rating classification (average of Moody's and S\&P) & BBB/BBB- & 3 notches & B & AAA \\
\hline
\end{tabular}

Based on a sample of 105 infrastructure-related, US dollar-denominated international bonds issued by projects in 20 emerging economies (Argentina, Brazil, Chile, China, Colombia, Czech Rep., Dominican Rep., Hong Kong, India, Indonesia, Malaysia, Mexico, Panama, Philippines, Qatar, Russia, South Africa, South Korea, Thailand, and Venezuela).

On average, emerging-economy project bonds are issued at approximately 300 basis points above US Treasury securities of comparable maturities, have a surprisingly high issue size of US\$278 million, a maturity of just under 12 years and are rated slightly below investment grade (exactly between BBB- and BBB). Most project bonds are senior debt or issued against a collection of project receivables as asset-backed securities (ABS). The latter type of debt, while not explicitly senior obligations of the project, are issued as pari passu instruments that will become de facto senior once other unsubordinated debt comes into existence.

Unsecured debt tends to be rated higher than secured debt, possibly reflecting the fact that higher rated projects can afford to provide less security to their investors. In terms of geographic origin, international project bonds from Latin America and Asia are more numerous than from Eastern Europe, the Middle East, and Africa. All major project types are represented albeit with a particular concentration of issues in the energy, power, telecom, and transport sectors.

\section{Covenant Provisions}

A fruitful conceptual framework for analyzing projects and, in particular, their organizational, contractual, and financial design relies on the view of the firm as a nexus of contracts. First formulated in the seminal papers by Alchian and Demsetz (1972) and Jensen and Meckling (1976), it underlies much of modern corporate finance. The allocation of control rights and interaction of all constituent contracts of a firm (infrastructure project) motivate financing choices (Fama, 1990), determine corporate governance arrangements (Jensen and Meckling, 1976), and even provide a framework for project valuation (see Kaplan and Ruback, 1995 for an application in terms of discounted cash flows). Hence, we would expect bond covenants of projects that, by their very nature, most closely correspond to the stylized view of the firm as a nexus of contracts, to reflect and 
address conflicts of interests not only between different claimholders but also other stakeholders, such as host governments and customers, in the project.

Projects suffer from typical contracting problems arising from relationship specificity, sunk costs, and the associated "hold-up" problem that were first described in other areas of economics by Klein, Crawford, and Alchian (1978), and Williamson $(1979,1983)$. Three types of solutions have been proposed in the literature that balance incentives for ex-ante efficient investments and ex-post trade efficient: (i) writing contracts with proper legal remedies in case of breach of contract (Shavell, 1980 and 1984; Rogerson, 1984), (ii) agreeing on a rule for the re-negotiation of contracts (Aghion, Dewatripont and Rey, 1994), and (iii) writing option contracts (Nöldeke and Schmidt, 1995). In addition, the parties can always attempt to write a self-enforcing contract so that, as Jensen and Meckling (1976) have argued, conflicts of interest between bondholder and stockholder are resolved through the contractual and financial design of firms. This insight underlies much of our analysis of project bond covenants that we can take to be the contractual responses to the afore-mentioned contracting problems.

Since the presence of risky debt in a firm's capital structure can lead to ex post conflicts of interests between the firm's equity holders and bondholders, contractual devices such as debt covenants have evolved to mitigate their adverse consequences. For instance, companies that issue bonds either on a project (non-recourse) or corporate (on-balance sheet) basis, be it in domestic or in international markets, generally agree to a set of contractual covenants requiring them to take or to refrain from taking certain specified actions. Such actions are designed fundamentally to protect the interest of bondholders-safety and seniority of their claims, repayment, and legal remedies in the event of default-after the bonds have been issued. Covenant provisions contained in bond indentures typically take the form of restrictions on dividend, M\&A transactions, and asset disposals, limitations on indebtedness, requirements of third party guarantees, maintenance of good regulatory standing and, in certain circumstances, the establishment of offshore and debt service reserve accounts. Violations of such provisions usually trigger contractual penalties or renegotiation and might ultimately lead to default and court-supervised bankruptcy proceedings.

The ability to design and enforce solid bond covenants to protect the interest of bondholders is a critical factor for infrastructure projects located in developing countries in tapping offshore markets for financing. The complexity of infrastructure project finance transactions- 
involving multi-source financing structures, numerous public and private contracting parties, and intricate contractual arrangements and legal documentations, compounded by the weakness in the legal and institutional framework to protect investors interests-makes this task a challenging one.

The specific covenants included in a particular debt agreement and the extent to which such covenants effectively serve to protect the interests of creditors depend inter alia on the nature of the debt instruments, governing law, and the underpinning legal and institutional frameworks governing contract formation and enforcement. Given that the writing, negotiating, and monitoring of specific provisions are costly, two sets of considerations become relevant: the ease with which the stipulated covenants can be monitored, and the scope for potential opportunistic behavior that could lead to transfer of wealth from bondholders to shareholders.

More generally, investors are concerned about the availability of legal recourse that depends on the bond's terms and the quality of the legal and institutional environment in the host country. An examination of the project bond covenants in our sample reveals that project bond indentures contain the usual covenant provisions aimed at mitigating typical shareholderbondholder conflicts such as asset substitution, dividend policies, claim dilution, and underinvestment (Warner and Smith, 1997). In the absence of sufficient contractual protections, the outcome is likely to be an inefficiently low investment, often referred to as the under-investment phenomenon (Hart and Moore, 1988).

In addition, they contain two further categories of clauses that arise from the very specific nature of project finance. Project debt covenants include incentive provisions for the contractors, operators, and sponsors such as performance targets, mandatory penalties, and minimal equity participation in the project. They also contain institutional environment provisions that, in case of changes in the ambient regulatory, legal, or tax environment, trigger change of control and/or mandatory redemption of the debt that would assure bankruptcy and operating disruptions of the project. Akin to poison pills, such provisions strengthen the position of (foreign) creditors vis-àvis the host country and its policies.

From our 105 project bonds, we extract a subsample of 27 bonds for which we have detailed covenant information from offering circulars, regulatory filings, and rating analyses. As the 
following table shows, the summary statistics for the subsample mirror the financial characteristics of the full sample:

\begin{tabular}{|c|c|c|c|c|}
\hline Characteristics & Mean & Std. Dev. & Min. & Max. \\
\hline Spread over US Treasuries & 182 & 117 & 10 & 375 \\
\hline Amount* & 319.49 & 193.51 & 180.00 & 800.00 \\
\hline Maturity (years) ** & 10 & 3 & 5 & 18 \\
\hline Rating classification (average of Moody's and S\&P)*** & $\mathrm{BBB}+/ \mathrm{BBB}$ & 2 notches & $\mathrm{BB}$ & At \\
\hline \multicolumn{5}{|c|}{ (*) Ras Laffan issued the largest and AES China the smallest amount } \\
\hline \multicolumn{5}{|c|}{$\left({ }^{* *}\right)$ Ras Laffan has the longest and China Telecom the shortest maturity } \\
\hline$\left({ }^{* * *}\right)$ CEZ Finance has the highest and Fideicomiso Peta & co with the low & credit rating & & \\
\hline
\end{tabular}

Based on a subsample of infrastructure-related, USD-denominated international bonds issued by projects in 5 emerging economies (Chile, China, the Czech Republic, Mexico, the Philippines, and Qatar) for which full covenant information is available.

All project bonds in our sample are issued under New York Law. This particular segment of emerging market debt has often acted as an innovating force and contractual catalyst as the following example shows. While project bonds often contain collective action clauses such as qualified majority rules to limit inter-creditor conflicts of interests, comparable sovereign-bond indentures issued under New York law typically did not have such provisions until recently. However, established market practices seem to be changing as the Republic of Mexico recently offered a global bond with a qualified majority clause (February 2003) followed by Brazil (April 2003). ${ }^{5}$ In some sense, sovereign borrowers from emerging economies follow more established corporate precedent in order to insure a better reception of the issue by investors.

A preliminary analysis shows that project covenant provisions differ widely in their stringency. The more projects are removed from their sponsors as measured by specific references to their limited-recourse status (about 52 percent), the more restrictive their covenants tend to be. As stand-alone investments representing a single source for cash flows, debtholders require additional assurance that cash flows (and operations) are not used to enhance shareholder value to their detriment.

5 For more on the Mexican issue see Dailami and Kim, "Mexico's Collective Action Clause Bond," International Finance Briefing Note 24, March 7, 2003, The World Bank; the Brazilian issue is discussed in the International Finance Review, May 2003. 


\begin{tabular}{|c|c|c|c|}
\hline Category & Provision/Restriction & Type & Frequency \\
\hline \multirow[t]{7}{*}{ Project driven } & Limited recourse status & & $52.31 \%$ \\
\hline & Limited recourse definition & & $28.57 \%$ \\
\hline & Collateral & & $33.33 \%$ \\
\hline & & Fixed asset & $14.28 \%$ \\
\hline & & Receivables & $38.09 \%$ \\
\hline & & Off-shore trust account & $28.57 \%$ \\
\hline & Intercreditor Agreement & & $9.52 \%$ \\
\hline \multirow[t]{4}{*}{ Stakeholder incentives } & Capitalization requirements & & $19.05 \%$ \\
\hline & Party-specific equity stakes & & $19.05 \%$ \\
\hline & Performance-contingent put provision & & $17.64 \%$ \\
\hline & Performance targets, penalties & & $4.76 \%$ \\
\hline \multirow[t]{3}{*}{ Government incentives } & Mandatory redemption for concession cancellation & & $23.80 \%$ \\
\hline & Redemption for change in tax law or regulation & & $66.67 \%$ \\
\hline & Maintenance of government approval, regulatory compliance & & $19.04 \%$ \\
\hline \multirow[t]{8}{*}{ Asset substitution } & Put provision & & $9.52 \%$ \\
\hline & Contingent put provision & & $17.64 \%$ \\
\hline & Cost overrun & & $9.52 \%$ \\
\hline & Asset sale, lease-back & & $85.71 \%$ \\
\hline & Transactions with affiliated firms & & $23.80 \%$ \\
\hline & Counter-party restrictions & & $9.52 \%$ \\
\hline & Nature of business & & $42.85 \%$ \\
\hline & Use of funds & & $23.80 \%$ \\
\hline \multirow[t]{9}{*}{ Claim dilution } & Additional indebtedness & & $73.68 \%$ \\
\hline & Lien limitations & & $100 \%$ \\
\hline & M\&A restrictions & & $95.23 \%$ \\
\hline & Collateral value preservation & & $19.04 \%$ \\
\hline & Modification of indenture & & $85.71 \%$ \\
\hline & Reporting requirements & & $80.95 \%$ \\
\hline & Maintenance of insurance & & $33.33 \%$ \\
\hline & Equity conversion & & $5.00 \%$ \\
\hline & Permission of highly-leveraged transactions & & $28.57 \%$ \\
\hline \multirow[t]{4}{*}{ Payments } & Dividends, debt-service coverage ratio restrictions & & $47.62 \%$ \\
\hline & Sinking fund & & $35.00 \%$ \\
\hline & Third-party guarantees, debt service reserves & & $26.31 \%$ \\
\hline & Default definition & & $85.71 \%$ \\
\hline \multirow[t]{2}{*}{ Underinvestment } & Call provisions & & $26.67 \%$ \\
\hline & Investment limitations & & $33.33 \%$ \\
\hline
\end{tabular}

Based on information extracted from the offering documents (registration filings, offering circulars, rating studies) available for a subsample of 27 infrastructure-related, USD-denominated international bonds. The Frequency column records the frequency of occurrence of the respective provision types in the bond covenants. In particular, we classified projectbond covenant provisions into 45 broad categories and seven instrument-specific classes and attributed for each bond indenture containing a particular clause or feature $a 1$, and 0 otherwise.

While all indentures contain sensibly the same standard provisions aimed at preventing asset substitution, claim dilution, cash payments, and underinvestment, two thirds of the bonds also include project-specific stipulations. Most telling are minimal ownership requirements (19 percent of covenants) for sponsors, operators, contractors, and off-takers. Clearly, such provisions are meant to align the interests of certain stakeholders crucial to the project's commercial success 
with debtholders. Equity stakes act as commitment and incentive devices for key players. Provisions specifying remedies in case of cost overruns ( 24 percent of indentures), performance targets ( 5 percent), capitalization requirements (19 percent), and restrictions on counter-parties (10 percent) further protect the interests of debtholders.

A second set of covenant provisions address the institutional environment and possible opportunistic behavior by regulators and host governments. Roughly one quarter of indentures ( 24 percent) provide for mandatory debt redemption in case of concession cancellations (a further 17 percent offer optional redemption at the discretion of the bondholders in case of completion, financing, or operating problems). Conversely, 22 percent of covenants stipulate that the projects are to maintain government approval and comply with all laws, rules, and regulations applicable to the project. The objective is clear: on the one hand, the project is not to give the host country any reason to intervene. On the other, mandatory redemption in case of concession cancellations forces the project into bankruptcy so that the ensuing disruption of service is meant to dissuade the host country from unilateral regulatory actions. In the same vein, 77 percent of all indentures require mandatory or optional early redemption in case of changes in tax regulation.

\section{Determinants of Credit Spreads}

The cost of international bond financing for infrastructure projects in emerging economies is a key determinant of their tariff structure and, hence, economic viability. Our analysis of at-issue credit spreads of emerging market project bonds over US Treasuries reveals how legal, regulatory, economic, and financial institutions in host countries influence risk perceptions and, hence, the cost of debt for infrastructure development. We find that market risk perception in terms of at-issue spreads over US Treasury bonds are a function of a project's contractual structure and its ambient institutions. Since it is nearly impossible to anticipate on all contingencies in writing the contract, and since parties might have an incentive for opportunistic behavior, contracts are always incomplete by their very nature and need to rely on other institutions for their execution. ${ }^{6}$ It emerges that the quality of the ambient institutional environment is an important factor for market risk perceptions and the initial pricing of project bonds.

\footnotetext{
6 According to the transaction-cost approach, contract incompleteness is attributed to high transaction costs of writing, negotiating of contracts, and costs associated with monitoring contractual performance; see, for instance, Joskow (1987, 1988), Hart (1988), and Aghion and Bolton (1992).
} 
In theory, the (second-best) optimal choice of debt contracts can mitigate some of these risks as long as investors can threaten the firm with a future cost that one could interpret as collateral realization (Diamond, 1984; Gale and Hellwig, 1985; or Bolton and Scharfstein, 1990), withholding of new financing (Gromb, 1999), or liquidation (Hart and Moore, 1994 and 1998). In practice, the effectiveness of such covenant provisions critically hinges on the quality of the ambient legal institutions required to make the investors' threat credible and, thus, the contract selfenforcing. Hence, we would expect pricing to be a function of the institutional environment and project attributes bonds in addition to the nature of their covenants.

The institutional, political, and economic environment feeds through to project-bond pricing through the market's collective assessment of the issue's systematic and idiosyncratic risks and, hence, the premium that bondholders demand over comparable default-free sovereign bonds. First and foremost, investors take into account the likelihood of debtor default and recovery in bankruptcy. In the context of project bonds, counter-party (off-take), price, and demand risk drive idiosyncratic risk perceptions, while political, macroeconomic, and institutional factors such as definition and enforcement of property rights determine the systematic ones. The institutional environment, often overlooked or taken for granted by researchers and practitioners alike, is of particular importance as it can mitigate or amplify the degree to which counter-party and political risks feed through to creditors. Put differently, deficiencies in the institutional development of a host country might exacerbate the market's perception of counter-party and other risk factors in pricing bonds. It also explains why project-rating analyses pay particular attention not only to the project's contractual structure but also to its ambient legal, regulatory, and political environment.

Traditionally, empirical studies of credit spreads have analyzed the dynamic aspects rather than cross-sectional ones such as the legal and institutional factors affecting corporate bonds (Longstaff and Schwartz, 1995 or Duffee, 1998), reflecting the focus of much of the theoretical work in this area. However, recent work by Madan and Unal (2000) linking default rates to structural factors implies that credit spreads are linearly related to firm-specific and exogenous variables. In contrast the recent theoretical literature (e.g., Duffie and Singleton, 1999), this approach provides a solid theoretical foundation for the nascent empirical literature on the cross-sectional determinants of credit spreads. Closest to our analysis are Elton et al. (2001) who relate the crosssectional variation of US corporate yield spreads to factors other than default expectations such as taxes and equity risk factors. However, they do not study the impact of issuer-specific contractual 
and organizational design factors on credit spreads, nor the impact of institutional factors such as the quality of legal, regulatory, and political institutions.

In analyzing the determinants of (at-issue) spreads of project bonds, we relate project credit spreads over US Treasuries to the relevant issue information (amount, maturity, rating), a set of variables extracted from the bond's covenant provisions (seniority, collateral, etc.), industry indicator variables (energy, power, water, etc.), factors capturing financial and economic aspects of the underlying project, a set of host country economic indicators (GDP, growth, etc.), and a set of indices measuring a host country's quality of financial, legal, and political institutions in a cross-sectional random-effect regression framework. Tables 2 and 3 contain detailed summary statistics on our explanatory variables while table 5 describes the institutional variables in more detail.

More precisely, we estimate the following linear cross-sectional model of project credit spreads by random country-effects regressions:

$$
\begin{aligned}
S P R E A D_{i}= & \beta_{0}+\sum_{1 \leq k \leq K_{1}} \beta_{k} I S S U E_{k i}+\sum_{K_{1}<k \leq K_{2}} \beta_{k} B C O V_{k i}+\sum_{K_{2}<k \leq K_{3}} \beta_{k} 1_{I N D_{k}}+\sum_{K_{3}<k \leq K_{4}} \beta_{k} P R O J_{k i} \\
& +\sum_{K_{4}<k \leq K_{5}} \beta_{k} x_{k j}+\sum_{K_{5}<k \leq K_{6}} \beta_{k} I N S T_{k j}+\sum_{K_{6}<k \leq K_{7}} \beta_{k} B C O V_{k j} \cdot I N S T_{k j}+v_{i j}, v_{i j}=e_{i j}+u_{i}
\end{aligned}
$$

where the dependent variable SPREAD is the at-issue spread over US Treasuries of project $i$ 's bond, ISSUE the relevant issue information (amount, maturity, rating), $B C O V$ a set of variables the bond's covenant provisions (seniority, collateral, etc.), IND industry indicator variables (energy, power, water, etc.), PROJ capturing financial and economic aspects of the underlying project, $x$ a set of host country $j$ economic indicators (GDP, growth, etc.), INST indices measuring host country $j$ 's quality of financial, legal, and political institutions, and the last term interacts covenant provisions and institutional variables. While table 4 in the Appendix provides detailed results of our empirical analysis, the following diagrams summarize our findings in terms of the institutional, issue terms, and sector effects. 


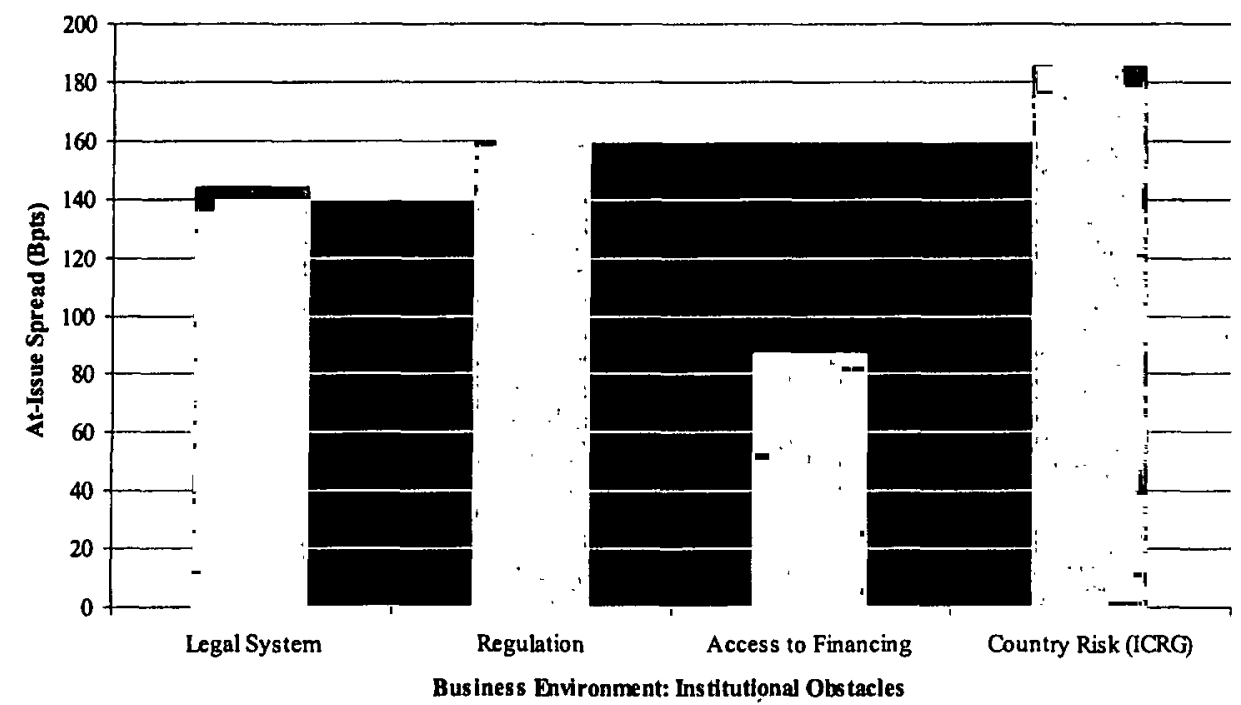

Results from cross-sectional regression analysis of the at-issue credit spreads of 105 international project bonds from emerging economies suppressing various control variables. Institutional variables derived from the 1996/97 and 2000/01 Business Environment Surveys conducted by the World Bank. The bars represent the effect on credit spreads of an increase by one category in an institution perceived as an obstacle to business (e.g., going from minor to moderate obstacle) with dark bars representing variables statistically significant at the I percent or 5 percent level.

Among the institutional variables, legal and regulatory obstacles have the largest and statistically most significant effect: an increase of 1 in the obstacle score for the judiciary increases at-issue spreads by 144 basis points (bpts), for the regulatory and tax variable by 159 bpts (see specification 1 in table 4). Similarly, a 10 point increase in the ICRG composite risk index (e.g., from low to moderate country risk) increases project bond credit spreads by $150 \mathrm{bpts}$. Insufficient financial development also widens at-issue spreads but the effect is not statistically significant: the recourse to global debt market helps to overcome financing constraints that local firms typically face as an institutional impediment. These findings underline the importance of the ambient legal framework and institutional development for access to external financing, first pointed out by La Porta et al. (1997 and 1998). Similarly, Modigliani and Perrotti (1998) argue that quality of legal enforcement is a determinant of the form of debt borrowers choose.

Regarding bond and project characteristics (specification 2 in table 4) it emerges that maturity and credit ratings are two very significant determinants of at-issue spreads: one additional year of maturity increases spreads by 2 bpts. A decrease in project rating by one notch (e.g., from $\mathrm{BBB}+$ to $\mathrm{BBB}$ ) increases spreads by 31 bpts, a similar decrease in the host country's rating by 
24 bpts. Since project and host country ratings often go hand in hand, the combined effect is a substantial 54 basis points. These findings mirror the results of King and Khang (2002) who, in their analysis of US corporate yield spreads, establish similar rating effects in addition to typical financial determinants such as leverage and free-cash flow quality, in themselves factors affecting credit ratings.

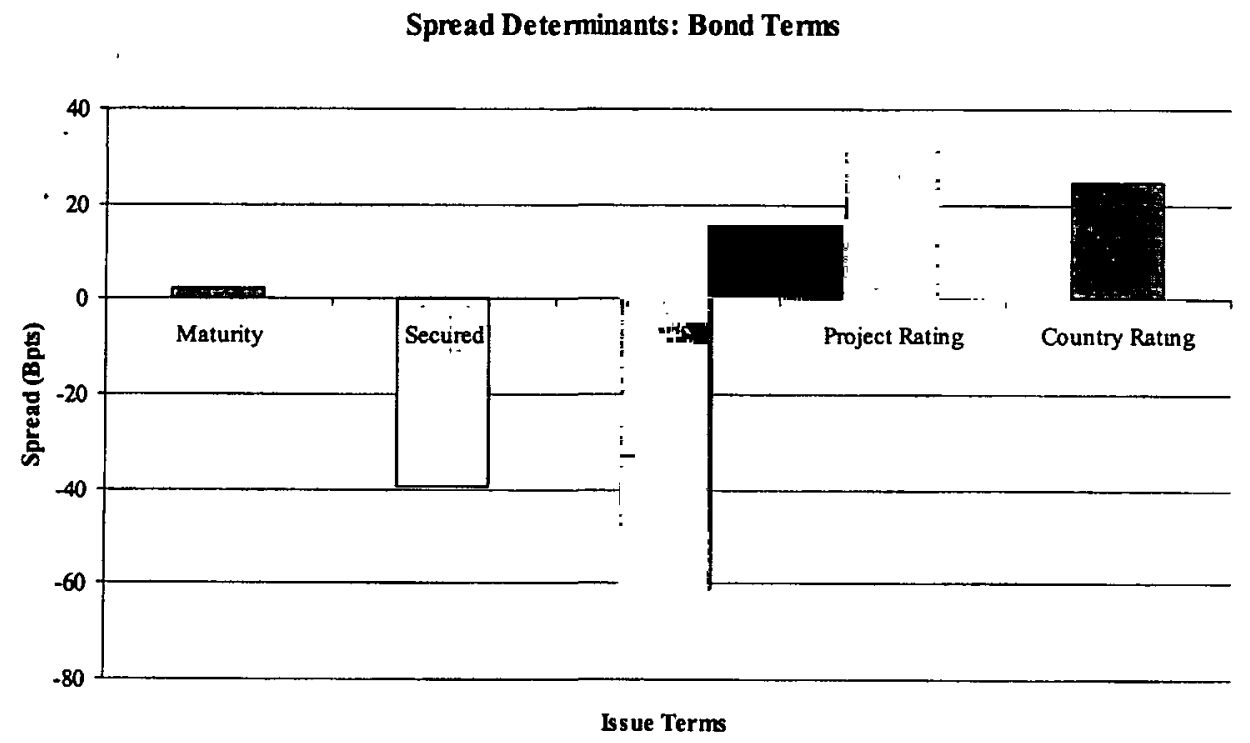

In terms of project type, water and transportation projects come to the market at, respectively, 135 and 233 bpts higher than other projects. A possible explanation might lie in the fact that these two types of projects are particularly vulnerable in terms of asset-specificity, unilateral redefinition of property rights, and demand risk. 
Project Type: Asset Specificity and Revenue Potential

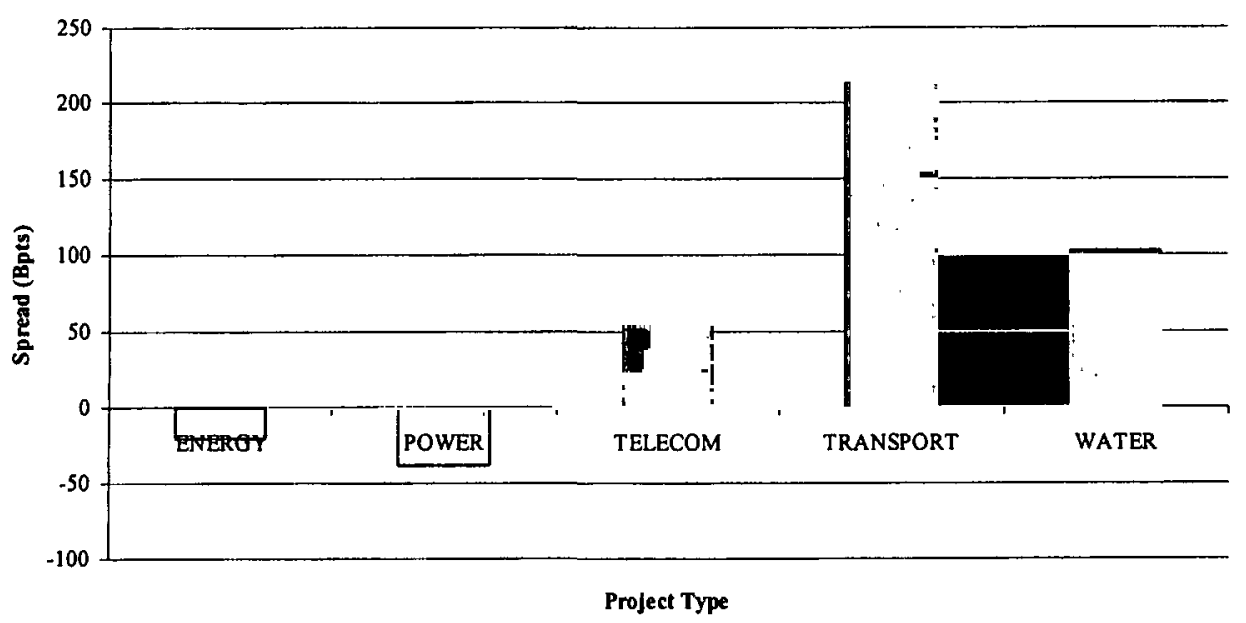

The analysis suggests that covenant protection and, more generally, contractual devices alone are insufficient to overcome shortcomings in the host country's legal, financial, and political institutions. Investors, through their pricing behavior, take into account the quality of the ambient institutional environment. Given the very specific nature of the assets, the scope for opportunistic behavior and the concentrated nature of economic and financial risk inherent in project finance, well-functioning legal, economic, and political institutions provide better investor protection than bond covenants. Bondholders, in turn, reward projects located in host countries that adhere to the rule of law with tighter credit spreads and, hence, lower funding costs. Instead, covenants can serve as incentive devices to all stakeholders in a project including host governments and regulators. Built around easily understood and enforced standard provisions, they include provisions that make it very costly for local parties-government and direct stakeholders-to enhance their own stakes in the project to the detriment of bondholders.

Our findings mirror the results of Elton et al. (2001) who show for a sample of US corporate bonds that expected default accounts for a surprisingly small fraction of the credit spread. While tax effects explain a substantial portion of the spread, the authors find that factors explaining risk premia for common stock also drive credit spreads.

\section{Discussion and Conclusion}

This note highlights several important characteristics of international project bond markets. It provides an empirical perspective on typical project-bond covenant provisions on the basis of a sam- 
ple of project-related fixed income securities issued in international capital markets from January 1993 to March 2002. Furthermore, we complement the discussion of covenant provisions with an analysis of the degree to which the level of institutional development of the projects' host countries matters for the pricing of the bonds.

We find that fixed income investors price both the contractual design of the actual debt security and its ambient institutional environment. As a more detailed analysis of typical projectbond covenants reveals, issuers anticipate concerns by lenders that arise from the particular nature of infrastructure projects, i.e., the assets' location specificity, threat of renegotiation, unilateral regulatory changes, and unilateral redefinition of property rights. At the same time, covenants also strive to implement managerial incentives for owners and operators of project that, hitherto, was thought of as falling into the domain of shareholders. Hence, we conclude that bondholders play a much more active role in the design and governance of project bonds than is the case for traditional corporate bonds.

Our analysis also shows that one cannot view the contractual arrangements of project in isolation from the ambient legal and regulatory environment. Controlling for economic and financial development of the host country, we find that the level of institutional development and, especially, proxies for the rule of law significantly affect market risk perceptions and project-bond pricing. This find is hardly surprising in light of our covenant analysis. In the last consequence, private contracting - rarely able to specify a complete contract - needs to rely on host-country legal institutions to enforce local provisions, contracts and property rights. Hence, two conclusions emerge. First, private contractual arrangements and ambient legal institutions are complements rather than substitutes. Second, investing in building appropriate institutions can decrease the cost of infrastructure development beyond their immediate benefits for society at large. 


\section{References}

Aghion, P. and Patrick Bolton (1992), "An Incomplete Contracts Approach to Financial Contracting," Review of Economic Studies 59(3): 473-494.

Agion, P., M. Dewatripont, and P. Ray, 1994. "Renegotiation Design with Unverifiable Information," Econometrica, Vol. 62, No.2, March 1994, pp. 257-282.

Brealey, R.A., I. A. Cooper, and M.A. Habib (1996), "Using Project Finance to Fund Infrastructure Investments,” Journal of Applied Corporate Finance 9: 25-38.

Dailami, M. and R. Hauswald (2001), "Credit Spread Determinants and Interlocking Contracts: A Clinical Study of the Ras Gas Project," mimeo, The World Bank.

Dailami, M., and D. Leipziger. (1998), "Infrastructure Project Finance and Capital Flows: A New Perspective." World Development, (Vol. 26, No. 7), July 1998.

Duffee, G.R. (1998), "Treasury Yields and Corporate Bond Yield Spreads: An Empirical Analysis," Journal of Finance 53: 2225-2242.

Duffie, D. and K.J. Singleton (1999), "Modelling Term Structures of Defaultable Bonds," Review of Financial Studies 12: 687-720.

Elton, E., M. Gruber, D Agrawal, and C. Mann (2001), "Explaining the Rate Spread on Corporate Bonds," Journal of Finance 56: 247-277.

Esty, B.C. (1999), "Petrozuata: A Case Study of the Effective Use of Project Finance," Journal of Applied Corporate Finance 12: 26-42.

Fama, E.F. (1990), "Contract Costs and Financing Decisions," Journal of Business 63: 71-91.

Green, Richard C. 1984. "Investment Incentives, Debt, and Warrants," 13 Journal of Financial Economics, March, 115-136.

Jensen, M. and W. Meckling (1976), "Theory of the Firm: Managerial Behavior, Agency Costs, and Capital Structure." Journal of Financial Economics 3 (1976), 305-60.

John, K., 1987, "Risk-Shifting Incentives and Signalling through Corporate Capital-Structure", Journal of Finance, July, 623-641.

Joskow, Paul L., 1987. "Contract Duration and Transactions Specific Investment: Empirical Evidence from Coal Markets," 77 American Economic Review 168.

Joskow, Paul L. (1988), "Asset Specificity and the Structure of Vertical Relationships: Empirical Evidence," in Journal of Law, Economics, and Organization, Vol. 4, No. 1, Spring 1988.

Kaplan, S.K. and R. Ruback (1995), "The Valuation of Cash Flow Forecasts: An Empirical Analysis," Journal of Finance 50: 1059-1093.

King, T. and K. Khang (2002), "On the Cross-sectional and Time-series Relation between Firm Characteristics and Corporate Bond Yield Spreads," mimeo, University of WisconsinMilwaukee.

Klein, B., R. Crawford, and A. Alchian. 1978. "Vertical Integration, Appropriate Rents, and the Competitive Contracting Process." Journal of Law and Economics, 21:297-326. 
La Porta, Rafael; Lopez-de-Silanes, Florencio; Shleifer, Andrei; and Vishny, Robert W. 1998, Law and Finance, Journal of Political Economy 106, 1113-1155.

La Porta, Rafael; Lopez-de-Silanes, Florencio; Shleifer, Andrei; and Vishny, Robert W. 1997, Legal Determinants of External Finance, Journal of Finance 52, 1131-1150.

Longstaff, Francis A. and Eduardo S. Schwartz (1995), "A Simple Approach to Valuing Risky Fixed and Floating Rate Debt," Journal of Finance 50: 789-819.

Madan, D. and H. Unal (2000), "A Two-Factor Hazard Rate Model for Pricing Risky Debt and the Term Structure of Credit Spreads," Journal of Financial and Quantitative Analysis 35: 4365.

Modigliani, Franco and Enrico Perotti (1998), "Security versus Bank Finance: the Importance of a Proper Enforcement of Legal Rules," mimeo, MIT.

Nöldeke, G. and K. Schmidt, 1995, "Option Contracts and Renegotiation: A Solution to the HoldUp Problem," Rand Journal of Economics, Vo. 26, No. 2, Summer 1995, pp. 163-179.

Randolph, G. and A. Schrantz (1997), "The Use of the Capital Markets to Fund the Ras Gas Project," Journal of Project Finance 3 (2).

Rogerson, W.P. 1984, "Efficient Reliance and Damage Measures for Breach of Contract," Rand Journal of Economics, Vol. 15 (1984), pp. 39-53.

Schwartz, Alan, 1997, "Contracting About Bankruptcy", The Journal of Law, Economics and Organization, V. 13, No. 1, pp. 127-146.

Smith, Clifford W., Jr., and Jerold B. Warner (1979), "On Financial Contracting: An Analysis of Bond Covenants," 7 Journal of Financial Economics 1979: 117-161.

Williamson, O. 1979. "Transaction-Cost Economics: The Governance of Contractual Relations." Journal of Law and Economics. Vol. 22 (1979), pp. 233-261.

Williamson, O. 1983. "Credible Commitments: Using Hostages to Support Exchange." The American Economic Review. Sept. 1983. 


\section{APPENDIX}

\section{Table 1}

\section{Project Bonds Summary Statistics}

This table presents summary statistics of various attributes of the global project bonds represented in our sample that are primarily drawn from emerging economies by issue type.

\begin{tabular}{|c|c|c|c|c|c|}
\hline Type & $\mathbf{N}$ & Spread & Amount & Maturity & $\begin{array}{c}\text { Moody's } \\
\text { Rating }\end{array}$ \\
\hline Emerging economies & 105 & 297.80 & 278.07 & 11.82 & Baa3 \\
\hline Latin America & 56 & 333.64 & 233.40 & 10.46 & $\mathrm{Baa3}$ \\
\hline Asia & 43 & 251.94 & 322.91 & 13.38 & Baa3 \\
\hline Europe & 3 & 208.33 & 200 & 7.33 & Baa3 \\
\hline Middle-East and North Africa & 2 & 162.5 & 600 & 13.77 & A3 \\
\hline Africa & 1 & 802.17 & 396.825 & 30 & Baal \\
\hline Fixed rate & 98 & 296.43 & 287.14 & 12.27 & Baa2 \\
\hline Variable rate & 7 & 316.96 & 171.86 & 5.52 & $\mathrm{~A} 3$ \\
\hline Senior & 94 & 293.11 & 289.75 & 12.5 & Baa3 \\
\hline Secured & 34 & 343.46 & 237.20 & 12.4 & Bal \\
\hline Unsecured & 62 & 276.10 & 307.98 & 11.69 & Baa2 \\
\hline Asset-backed & 42 & 312.07 & 248.73 & 12.30 & $\mathrm{Baa} 2$ \\
\hline Chemical & 1 & 227.30 & 250.00 & 22 & Baa3 \\
\hline Energy & 39 & 312.60 & 322.42 & 11.4 & Baal \\
\hline Power & 38 & 254.50 & 227.90 & 13.1 & Baal \\
\hline Telecom & 12 & 310.40 & 286.67 & 9.01 & Baa2 \\
\hline Transmission & 6 & 359.80 & 181.50 & 8.36 & Baal \\
\hline Transport & 9 & 432.20 & 321.20 & 13.1 & Bal \\
\hline Water & 4 & 418.50 & 192.88 & 9.86 & $\mathrm{Ba} 2$ \\
\hline Other & 3 & 230.20 & 201.17 & 8.95 & Bal \\
\hline
\end{tabular}




\section{Table 2}

\section{Economic Indicators and Institutional Environment}

The country variables are 1995-1999 averages where per capita GDP is real GDP per capita in USD, Inflation log difference of the consumer price index, Growth the GDP growth rate in current USD, and Financing, Legal, and Corruption Obstacle are summary business environment variables from firm responses to the World Business Environment Survey (WBES). They take integer values 1 to 4 , with higher values indicating greater obstacles. Firm variables are averaged over all firms in each country. The last table provides more detailed variable definitions and explanations.

\begin{tabular}{|c|c|c|c|c|c|c|c|c|}
\hline \multirow[b]{2}{*}{ Country } & \multirow[b]{2}{*}{ GDP per capita } & \multirow[b]{2}{*}{ Inflation } & \multicolumn{5}{|c|}{ ICRG } & \multirow{2}{*}{$\begin{array}{c}\text { Corruption } \\
\text { Obst. }\end{array}$} \\
\hline & & & Growth & Credit Rating & Composite & Financing Obst. & Legal Obst. & \\
\hline Argentina & 7990 & 0.06 & 1 & $\mathrm{Ba} 3 / \mathrm{B} 1$ & 73.21 & 2.990 & 2.327 & 2.622 \\
\hline Brazil & 4486 & 16.07 & .8 & B2 & 65.19 & 2.692 & 2.543 & 2.490 \\
\hline Chile & 5001 & 5.97 & 4.4 & Baal & 78.42 & 2.410 & 1.990 & 1.867 \\
\hline China & 677 & 4.74 & 7.6 & A3 & 73.42 & 3.347 & 1.564 & 2.031 \\
\hline Colombia & 2383 & 16.67 & -0.6 & Baa3 & 60.74 & 2.640 & 2.370 & 2.780 \\
\hline Czech Republic & 5170 & 7.37 & 1.6 & Al & 79.79 & 3.136 & 2.126 & 2.136 \\
\hline Dominican Republic & 1742 & 7.11 & 5.2 & B1 & 69.89 & 2.640 & 2.482 & 2.936 \\
\hline Hong Kong & 22619 & 3.75 & 0 & A3 & 80.08 & 1.859 & 1.323 & 1.250 \\
\hline India & 414 & 8.32 & 4.6 & Bal & 66.82 & 2.548 & 2.011 & 2.797 \\
\hline Indonesia & 1044 & 17.56 & 0 & B3 & 60.69 & 2.860 & 2.198 & 2.630 \\
\hline Korea & 11480 & 4.29 & 3.8 & $\mathrm{Baa2}$ & 78.51 & 2.291 & 1.905 & 2.161 \\
\hline Malaysia & 4539 & 3.40 & 2.6 & Al & 76.53 & 2.316 & 1.685 & 1.852 \\
\hline Mexico & 3395 & 21.70 & 1.4 & $\mathrm{Ba} 2$ & 68.55 & 3.192 & 2.835 & 3.327 \\
\hline Panama & 3124 & 0.98 & 1.6 & Baal & 69.45 & 2.101 & 2.474 & 2.859 \\
\hline Philippines & 127 & 7.45 & 1.4 & Bal & 69.91 & 2.680 & 2.283 & 3.110 \\
\hline Qatar & & 3.58 & & $\mathrm{Bal}$ & 70.05 & 2.915 & 1.659 & 3.149 \\
\hline Russia & 2222 & 49.40 & -1 & $\mathrm{Ba} 2$ & 59.99 & 3.210 & 2.130 & 2.553 \\
\hline South Africa & 3936 & 7.07 & 0.6 & Baa3 & 72.75 & 2.382 & . & 2.598 \\
\hline Thailand & 2839 & 4.83 & 1 & A2 & 73.16 & 3.112 & 2.125 & 3.471 \\
\hline Venezuela & 3483 & 41.55 & -1.2 & $\mathrm{Ba} 3$ & 65.73 & 2.566 & 2.719 & 3.031 \\
\hline
\end{tabular}


Table 3

\section{Summary Statistics and Correlations}

Summary statistics are presented in Panel A and correlations are presented in Panel B. N refers to the number of bonds, countries, or WBES firm-level observations for the 20 countries represented in our sample. GDP, Inflation, Growth, and Financing, Legal, and Corruption Constraints are as previously defined. The various other financing, legal, and corruption variables are average responses by firms to the WBES questionnaire. Higher numbers indicate greater obstacles, with the exception of "Firms have to make 'additional payments' to get things done" and "Firms know the amount of 'additional payments' in advance". Detailed variable definitions and sources are contained in the last table.

Panel A: Summary Statistics

\begin{tabular}{|c|c|c|c|c|c|c|}
\hline Variable & Label & Obs. & Mean & Std. Dev. & Min & $\operatorname{Max}$ \\
\hline Spread over US Treasuries & SPREAD & 105 & 297.80 & 173.81 & 10 & 802.172 \\
\hline Amount issued & AMOUNT & 105 & 278.07 & 201.62 & 23 & 1000 \\
\hline Maturity (years) & MAT & 105 & 11.82 & 10.5 & 2.97 & 100 \\
\hline Credit rating index & CRI & 105 & 8.57 & 3.22 & 0 & 14 \\
\hline Country credit rating index & CCRI & 105 & 9.06 & 3 notches & $\mathrm{Al}$ & B3 \\
\hline Inflation & NFF & 105 & 11.96 & 11.39 & .61 & 49.40 \\
\hline GDP per capita & GDPCAP & 105 & 3905.42 & 3397.53 & 414 & 22618.60 \\
\hline GDP (million \$) & GDP & 105 & 280.3 & 266.05 & 8.8 & 870.2 \\
\hline Economic growth & GROWTH & 105 & 2.15 & 2.40 & -1.2 & 7.6 \\
\hline Infrastructure development & NFRA & 105 & 2.21 & 0.38 & 1.35 & 3.23 \\
\hline Financing & FINANCE & 105 & 2.79 & 0.38 & 1.86 & 3.35 \\
\hline Exchange rate & FXRATE & 105 & 2.65 & 0.65 & 1.38 & 3.63 \\
\hline Quality of Legal Institutions & LEGAL & 105 & 2.19 & 0.50 & 0 & 2.84 \\
\hline Corruption & CORRUPT & 105 & 2.60 & 0.60 & 1.25 & 3.47 \\
\hline Taxes \& regulation & TREG & 105 & 2.76 & 0.60 & 1.50 & 3.61 \\
\hline Policy instability and uncertainty & POLINST & 105 & 2.86 & 0.57 & 1.47 & 3.64 \\
\hline
\end{tabular}


Panel B: Correlation Matrix of Key Variables

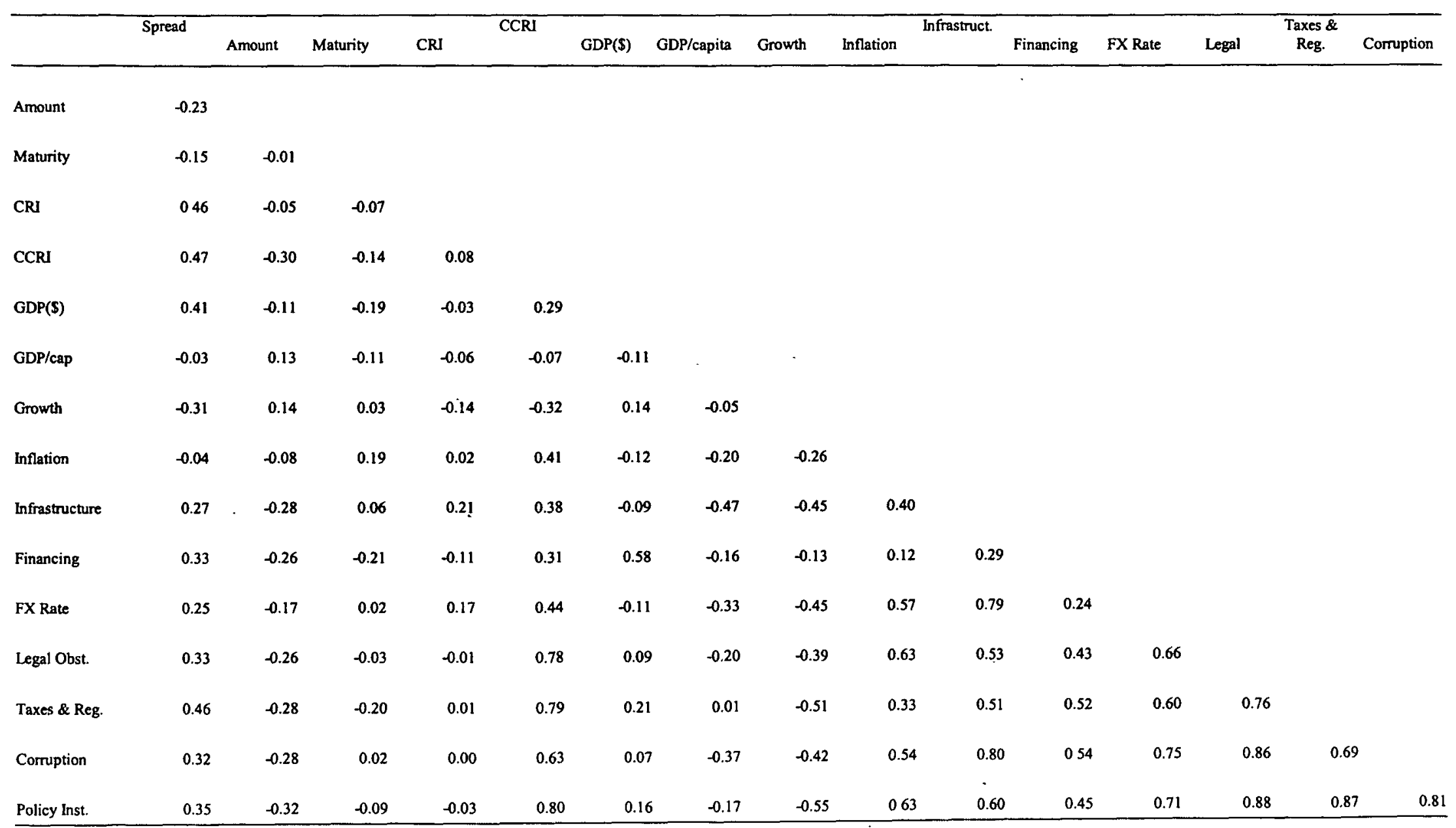


Table 4

Economic and Institutional Determinants of Project Bond Spreads

$$
\begin{aligned}
S P R E A D_{i}= & \beta_{0}+\sum_{1 \leq k \leq K_{1}} \beta_{k} I S S U E_{k i}+\sum_{K_{i}<k \leq K_{2}} \beta_{k} B C O V_{k j}+\sum_{K_{2}<k \leq K_{3}} \beta_{k} 1_{I N D_{k j}}+\sum_{K_{3}<k \leq K_{4}} \beta_{k} P R O J_{k i} \\
& +\sum_{K_{4}<k \leq K_{5}} \beta_{k} x_{k j}+\sum_{K_{s}<k \leq K_{6}} \beta_{k} I N S T_{k j}+\sum_{K_{6}<k \leq K_{7}} \beta_{k} \dot{B} C O V_{k j} \cdot I N S T_{k j}+v_{i j}, v_{i j}=e_{i j}+u_{i}
\end{aligned}
$$

where the dependent variable $S P R E A D$ is the project bond's at-issue spread over US Treasuries, ISSUE the relevant issue information (amount, maturity, rating), BCOV the bond's covenant provisions (seniority, collateral, etc.), IND industry indicator variables (energy, power, water, etc.), $P R O J$ a set of variables capturing financial and economic aspects of the underlying project, $x$ a set of host country $j$ economic indicators (GDP, growth, etc.), INST indices measuring host coun-

\begin{tabular}{|c|c|c|c|}
\hline Specification & 1 & & 2 \\
\hline \multirow[t]{2}{*}{ Constant } & 234.2358 & Constant & -254.5744 \\
\hline & $(0.3147)$ & & $(0.0318)$ \\
\hline Economic indicators: & & Economic indictors: & \\
\hline \multirow[t]{2}{*}{ GDP in USD millions } & 0.0689 & Country credit rating & -39.4783 \\
\hline & $(0.3873)$ & & $(0.2219)$ \\
\hline \multirow[t]{2}{*}{ Growth } & -5.8360 & Issue terms: & \\
\hline & $(0.1662)$ & Issue credit rating & 31.6986 \\
\hline Institutional obstacles: & & & $(0.0000)$ \\
\hline \multirow[t]{2}{*}{ Financing constraints } & 87.5000 & Amount & -0.0008 \\
\hline & $(0.1238)$ & & $(0.9891)$ \\
\hline \multirow[t]{2}{*}{ Legal obstacles } & 144.0655 & Maturity & 2.0267 \\
\hline & $(0.0333)$ & & $(0.0535)$ \\
\hline \multirow[t]{2}{*}{ Change in legal confidence } & -142.9761 & Secured & -39.4783 \\
\hline & $(0.2310)$ & & $(0.2219)$ \\
\hline \multirow[t]{2}{*}{ Policy instability } & -321.8449 & Unsecured & -61.1755 \\
\hline & $(0.0000)$ & & $(0.0722)$ \\
\hline \multirow[t]{2}{*}{ Taxes and regulation } & 159.8684 & Asset-backed & 49.5075 \\
\hline & $(0.0311)$ & & $(0.2011)$ \\
\hline \multirow[t]{2}{*}{ ICRG composite risk index } & 18.4925 & Guaranteed & 24.7833 \\
\hline & $(0.0000)$ & & $(0.0219)$ \\
\hline \multirow[t]{9}{*}{ ICRG corruption index } & -174.3331 & Sector & \\
\hline & & Energy & 54.3452 \\
\hline & & & $(0.2912)$ \\
\hline & & Power & -17.4807 \\
\hline & & & $(0.7434)$ \\
\hline & & Telecommunications & 56.7352 \\
\hline & & & $(0.3623)$ \\
\hline & & Transportation & 233.3951 \\
\hline & & & $(0.0001)$ \\
\hline
\end{tabular}
try $j$ 's quality of financial, legal and political institutions, and the last term an interactive one. 


\begin{tabular}{|c|c|c|c|}
\hline Specification & 1 & & 2 \\
\hline & \multirow{2}{*}{\multicolumn{2}{|c|}{ Water }} & 135.3451 \\
\hline & & & $(0.0543)$ \\
\hline & \multirow{2}{*}{\multicolumn{2}{|c|}{ Transmission }} & -107.5791 \\
\hline & & & $(0.0893)$ \\
\hline Adjusted $\mathbf{R}^{2}$ & 0.46 & & 0.54 \\
\hline Observations & 105 & & 103 \\
\hline No. of countries & 20 & & 20 \\
\hline
\end{tabular}




\section{Table 5}

\section{Variable Definitions and Data Sources}

The following table summarized our explanatory variables in terms of definition and origin. Together with our data from the World Bank's World Development Indicators (WDI), it contains all variables extracted from the World Business Environment Survey.(WBES) and, in particular, the relevant underlying questions and possible answer choices in the firm survey.

\begin{tabular}{|c|c|c|c|}
\hline Variable & Label & Definition & Source \\
\hline \multicolumn{4}{|c|}{ Economic Indicators } \\
\hline GDP & GDP & GDP in current U.S. dollars, observed in bond's issue year & WDI \\
\hline GDP per capita & GDPCAP & Real per capita GDP, observed in bond's issue year & WDI \\
\hline $\begin{array}{l}\text { Country Credit Rating } \\
\text { Index }\end{array}$ & CCRI & Index of host-country credit rating (average of Moody's and S\&P) & \\
\hline Credit Rating Index & CRI & Index of issue's credit rating (average of Moody's and S\&P) & \\
\hline Growth & GROWTH & Growth rate of GDP, observed in bond's issue year & WDI \\
\hline Inflation rate & INFLAT & $\begin{array}{l}\text { Log difference of Consumer Price Index, observed in bond's issue } \\
\text { year }\end{array}$ & WDI \\
\hline \multicolumn{3}{|c|}{$\begin{array}{l}\text { ICRG Corruption Index ICRGCORR International Country Risk Group index of host-country corruption } \\
\text { (rescaled: higher values correspond to more corruption) }\end{array}$} & $\begin{array}{l}\text { PRS } \\
\text { Group }\end{array}$ \\
\hline \multirow{2}{*}{\multicolumn{4}{|c|}{$\begin{array}{l}\text { ICRG Composite Index ICRGCOMP International Country Risk Group index of host-cou } \\
\text { economic and financial risk (rescaled: higher values } \\
\text { higher risk) } \\
\text { Major Environment Categories }\end{array}$}} \\
\hline & & & \\
\hline & & \multicolumn{2}{|l|}{$\begin{array}{l}\text { Each firm was asked to select three major business impediments out } \\
\text { of } 12 \text { broad categories to which the following variables belong. }\end{array}$} \\
\hline Financing Obstacle & FIN & $\begin{array}{l}\text { How problematic is financing for the operation and growth of your } \\
\text { business: no obstacle (1), a minor obstacle (2), a moderate obstacle } \\
\text { (3) or a major obstacle (4)? }\end{array}$ & WBES \\
\hline Legal Obstacle & LEGAL & $\begin{array}{l}\text { How problematic is functioning of the judiciary for the operation } \\
\text { and growth of your business: no obstacle (1), a minor obstacle (2), a } \\
\text { moderate obstacle (3) or a major obstacle (4)? }\end{array}$ & WBES \\
\hline $\begin{array}{l}\text { Change in Legal Confi- } \\
\text { dence }\end{array}$ & DLEG & $\begin{array}{l}\text { Difference in reply over three years to: I am confident that the legal } \\
\text { system will uphold my contract and property rights in business dis- } \\
\text { putes: (1) fully agree, (2) agree in most cases, (3) tend to agree, (4) } \\
\text { tend to disagree, (5) disagree in most cases, (6) fully disagree }\end{array}$ & WBES \\
\hline $\begin{array}{l}\text { Taxes and Regulation } \\
\text { Obstacle }\end{array}$ & TREG & $\begin{array}{l}\text { How problematic are taxes and regulations for the operation and } \\
\text { growth of your business: no obstacle (1), a minor obstacle (2), a } \\
\text { moderate obstacle (3) or a major obstacle (4)? }\end{array}$ & WBES \\
\hline $\begin{array}{l}\text { Political Instability } \\
\text { Obstacle }\end{array}$ & POLITI & $\begin{array}{l}\text { How problematic is political instability for the operation and growth } \\
\text { of your business: no obstacle (1), a minor obstacle (2), a moderate } \\
\text { obstacle (3) or a major obstacle (4)? }\end{array}$ & WBES \\
\hline Corruption Obstacle & CORR & $\begin{array}{l}\text { How problematic is corruption for the operation and growth of your } \\
\text { business: no obstacle (1), a minor obstacle (2), a moderate obstacle } \\
\text { (3) or a major obstacle (4)? }\end{array}$ & WBES \\
\hline
\end{tabular}




\begin{tabular}{lllc}
\hline \multicolumn{1}{c}{ Variable } & Label & \multicolumn{1}{c}{ Definition } & Source \\
\hline Infrastructure Obstacle INFRA & $\begin{array}{l}\text { How problematic is infrastructure for the operation and growth of } \\
\text { your business: no obstacle (1), a minor obstacle (2), a moderate ob- } \\
\text { stacle (3) or a major obstacle (4)? }\end{array}$ \\
$\begin{array}{l}\text { Exchange Rate Obsta- FXRATE } \\
\text { cle }\end{array}$ & $\begin{array}{l}\text { How problematic are exchange rates for the operation and growth of WBES } \\
\text { your business: no obstacle (1), a minor obstacle (2), a moderate ob- } \\
\text { stacle (3) or a major obstacle (4)? }\end{array}$ \\
\hline
\end{tabular}




\section{Table 6}

\section{Project Bonds}

The following table provides a detailed overview of our sample by reporting each bond's issue terms and legal structure. The information comes from the issue documentation and third sources such as Bloomberg, IDC, and Thomson Financial Securities Data. Country refers to the host-country, the Maturity is the project bond's time to redemption in years, the At-issue Spread the bond's yield spread over maturity-matched US Treasury securities, the Host-Country Spread the sovereign spread of the country's EMBI Global (JP Morgan) country index over US Treasuries, and all the other variables are selfexplanatory.

\begin{tabular}{|c|c|c|c|c|c|c|c|c|c|}
\hline Country & Project & Sector & $\begin{array}{l}\text { Issue } \\
\text { Date } \\
\end{array}$ & $\begin{array}{c}\text { Ma- } \\
\text { turity }\end{array}$ & $\begin{array}{c}\text { Amoun } \\
t\end{array}$ & $\begin{array}{l}\text { At- } \\
\text { issue } \\
\text { Sprea } \\
\text { d } \\
\end{array}$ & $\begin{array}{c}\text { Host- } \\
\text { Coun- } \\
\text { try } \\
\text { Spread }\end{array}$ & Ratings & Structure \\
\hline ARGENTINA & CAPEX S.A. & Power & 9-Jan-98 & 6.40 & 105.00 & $\begin{array}{c}324.62 \\
5\end{array}$ & 559 & $\mathrm{BB}$ & $\begin{array}{l}\text { Senior, Un- } \\
\text { secured }\end{array}$ \\
\hline ARGENTINA & $\begin{array}{l}\text { Empresa Distri- } \\
\text { buidora de Ener- } \\
\text { gia Norte S.A. }\end{array}$ & Power & $\begin{array}{c}\text { 14-Aug- } \\
98\end{array}$ & 5.00 & 125.00 & $\begin{array}{c}246.37 \\
5\end{array}$ & 689 & BBB- & $\begin{array}{l}\text { Senior, Un- } \\
\text { secured }\end{array}$ \\
\hline ARGENTINA & $\begin{array}{l}\text { Inversora Elec- } \\
\text { trica de Buenos } \\
\text { Aires S.A. }\end{array}$ & Power & 24-Sep-97 & 5.00 & 100.00 & 266 & 314 & $\mathrm{BB}+$ & $\begin{array}{l}\text { Pari passu, } \\
\text { Asset } \\
\text { Backed }\end{array}$ \\
\hline ARGENTINA & $\begin{array}{l}\text { Inversora Elec- } \\
\text { trica de Buenos } \\
\text { Aires S.A. }\end{array}$ & Power & 24-Sep-97 & 7.00 & 130.00 & 292 & 314 & $\mathrm{BB}+$ & $\begin{array}{l}\text { Pari passu, } \\
\text { Asset } \\
\text { Backed }\end{array}$ \\
\hline ARGENTINA & Metrogas S.A. & Power & $\begin{array}{c}\text { 27-Mar- } \\
00\end{array}$ & 3.00 & 350.00 & 353 & 517 & B1 & $\begin{array}{l}\text { Senior, Se- } \\
\text { cured }\end{array}$ \\
\hline ARGENTINA & $\begin{array}{l}\text { Transportadora } \\
\text { de Gas del Norte } \\
\text { S.A. (TGN) }\end{array}$ & Energy & 27-Jun-97 & 7.00 & 24.00 & $\begin{array}{c}211.89 \\
1\end{array}$ & 344 & BBB- & $\begin{array}{l}\text { Senior, Un- } \\
\text { secured }\end{array}$ \\
\hline ARGENTINA & $\begin{array}{l}\text { Transportadora } \\
\text { de Gas del Norte } \\
\text { S.A. (TGN) }\end{array}$ & Energy & 25-Jul-00 & 12.00 & 175.00 & $\begin{array}{c}486.92 \\
6\end{array}$ & 620 & BBB- & $\begin{array}{l}\text { Senior, Un- } \\
\text { secured }\end{array}$ \\
\hline ARGENTINA & $\begin{array}{l}\text { Transportadora } \\
\text { de Gas del Sur } \\
\text { S.A. (TGS) }\end{array}$ & Energy & 25-Apr-00 & 3.00 & 150.00 & 423 & 638 & B1 & $\begin{array}{l}\text { Senior, Un- } \\
\text { secured }\end{array}$ \\
\hline BRAZIL & $\begin{array}{l}\text { Companhia } \\
\text { Petrolifera Mar- } \\
\text { lim }\end{array}$ & Energy & $26-S e p-00$ & 8.00 & 200.00 & 662 & 659 & B2 & $\begin{array}{l}\text { Senior, Se- } \\
\text { cured }\end{array}$ \\
\hline BRAZIL & $\begin{array}{l}\text { Companhia } \\
\text { Petrolifera Mar- } \\
\text { lim }\end{array}$ & Energy & 17-Dec-99 & 5.00 & 200.00 & 715 & 567 & B2 & $\begin{array}{l}\text { Senior, Se- } \\
\text { cured }\end{array}$ \\
\hline BRAZIL & $\begin{array}{l}\text { Eletrobras - Cen- } \\
\text { trais Eletricas } \\
\text { Brasileiras S.A. }\end{array}$ & Power & 27-Jun-96 & 8.00 & 250.00 & 338 & 681 & $\mathrm{~B}+$ & $\begin{array}{l}\text { Senior, Un- } \\
\text { secured }\end{array}$ \\
\hline BRAZIL & $\begin{array}{l}\text { Eletrobras - Cen- } \\
\text { trais Eletricas } \\
\text { Brasileiras S.A. }\end{array}$ & Power & 9-Jun-00 & 5.00 & 300.00 & 568 & 650 & $\mathrm{~B}+$ & $\begin{array}{l}\text { Senior, Un- } \\
\text { secured }\end{array}$ \\
\hline BRAZIL & $\begin{array}{l}\text { Espirito Santo } \\
\text { Centrais Eletri- } \\
\text { cas S.A. }\end{array}$ & Power & 28-Jul-97 & 10.00 & 500.00 & 387.5 & 323 & B1 & $\begin{array}{l}\text { Senior, Un- } \\
\text { secured }\end{array}$ \\
\hline
\end{tabular}




\begin{tabular}{|c|c|c|c|c|c|c|c|c|c|}
\hline Country & Project & Sector & $\begin{array}{l}\text { Issue } \\
\text { Date } \\
\end{array}$ & $\begin{array}{c}\text { Ma- } \\
\text { turity }\end{array}$ & $\begin{array}{c}\text { Amoun } \\
t\end{array}$ & $\begin{array}{c}\text { At- } \\
\text { issue } \\
\text { Sprea } \\
\text { d } \\
\end{array}$ & $\begin{array}{c}\text { Host- } \\
\text { Coun- } \\
\text { try } \\
\text { Spread } \\
\end{array}$ & Ratings & Structure \\
\hline BRAZIL & $\begin{array}{l}\text { LIGHT- Servicos } \\
\text { de Eletricidade } \\
\text { S.A. }\end{array}$ & Power & $13-$ Oct-00 & 5.00 & 23.00 & 403.5 & 697 & $\mathrm{~B} 1$ & $\begin{array}{l}\text { Pari-Passu, } \\
\text { Unsecured }\end{array}$ \\
\hline CHILE & Chilgener S.A. & Power & 26-Jan-96 & 10.00 & 200.00 & 99 & 793 & Baal & $\begin{array}{l}\text { Senior, Un- } \\
\text { secured }\end{array}$ \\
\hline CHILE & EDELNOR S.A. & Power & $\begin{array}{c}\text { 27-Mar- } \\
96\end{array}$ & 10.00 & 250.00 & $\begin{array}{c}148.96 \\
7\end{array}$ & 836 & Baal & $\begin{array}{l}\text { Senior, Un- } \\
\text { secured }\end{array}$ \\
\hline CHILE & $\begin{array}{l}\text { Empresa Electri- } \\
\text { ca del Norte } \\
\text { Grande S.A. }\end{array}$ & Power & 2-Apr-98 & 7.00 & 90.00 & 480 & 450 & Baal & $\begin{array}{l}\text { Senior, Un- } \\
\text { secured }\end{array}$ \\
\hline CHILE & $\begin{array}{l}\text { Empresa Electri- } \\
\text { ca Guacolda S.A. }\end{array}$ & Power & 29-Apr-96 & 7.00 & 80.00 & $\begin{array}{c}143.99 \\
2\end{array}$ & 729 & Baa3 & $\begin{array}{l}\text { Senior, Se- } \\
\text { cured }\end{array}$ \\
\hline CHILE & $\begin{array}{l}\text { Empresa Electri- } \\
\text { ca Pehuenche } \\
\text { S.A. }\end{array}$ & Power & 2-May-96 & 7.00 & 170.00 & 90 & 741 & Baal & $\begin{array}{l}\text { Senior, Un- } \\
\text { secured }\end{array}$ \\
\hline CHILE & Enersis S.A. & Power & $\begin{array}{c}\text { 26-Nov- } \\
96\end{array}$ & 10.00 & 300.00 & 82 & 498 & Baa1 & $\begin{array}{l}\text { Senior, Un- } \\
\text { secured }\end{array}$ \\
\hline CHILE & $\begin{array}{l}\text { SCL Terminal } \\
\text { Aereo Santiago } \\
\text { S.A. }\end{array}$ & $\begin{array}{c}\text { Trans- } \\
\text { port }\end{array}$ & 22-Dec-98 & 13.53 & 213.00 & 237.5 & 953 & Baa2 & $\begin{array}{l}\text { Senior, Se- } \\
\text { cured \& } \\
\text { Asset } \\
\text { Backed }\end{array}$ \\
\hline CHILE & $\begin{array}{l}\text { Telefonica CTC } \\
\text { Chile S.A. }\end{array}$ & Telecom & 25-Jul-96 & 10.00 & 200.00 & 83 & 700 & Baal & $\begin{array}{l}\text { Senior, Un- } \\
\text { secured }\end{array}$ \\
\hline CHILE & $\begin{array}{l}\text { Telefonica CTC } \\
\text { Chile S.A. }\end{array}$ & Telecom & 8-Jan-99 & 7.00 & 200.00 & 350 & 931 & Baal & $\begin{array}{l}\text { Senior, Un- } \\
\text { secured }\end{array}$ \\
\hline CHINA & $\begin{array}{l}\text { AES China Gen- } \\
\text { erating Co. Ltd. }\end{array}$ & Power & 19-Dec-96 & 10.00 & 180.00 & 375 & 479 & $\mathrm{Ba} 3$ & $\begin{array}{l}\text { Senior, Un- } \\
\text { secured }\end{array}$ \\
\hline CHINA & $\begin{array}{l}\text { Cathay Interna- } \\
\text { tional Limited }\end{array}$ & $\begin{array}{c}\text { Trans- } \\
\text { port }\end{array}$ & 15-Apr-98 & 10.00 & 350.00 & 745 & 440 & $\mathrm{Ba} 3$ & $\begin{array}{l}\text { Senior, Un- } \\
\text { secured }\end{array}$ \\
\hline CHINA & $\begin{array}{l}\text { China Mobile } \\
\text { (Hong Kong) } \\
\text { Ltd. }\end{array}$ & Telecom & 2-Nov-99 & 5.00 & 600.00 & 190 & 712 & $\begin{array}{c}\mathrm{A} 3 / \mathrm{BB} \\
\mathrm{B}\end{array}$ & $\begin{array}{l}\text { Senior, Un- } \\
\text { secured }\end{array}$ \\
\hline CHINA & $\begin{array}{l}\text { China Telecom } \\
\text { (Hong Kong) } \\
\text { Ltd. }\end{array}$ & Telecom & $31-$ Oct-00 & 5.00 & 690.00 & 240 & 657 & Baa2 & $\begin{array}{l}\text { Senior, Un- } \\
\text { secured }\end{array}$ \\
\hline CHINA & $\begin{array}{l}\text { GH Water Sup- } \\
\text { ply [Holdings] } \\
\text { Limited }\end{array}$ & Water & 22-Dec-00 & 10.00 & 400.00 & $\begin{array}{c}194.66 \\
7\end{array}$ & 741 & $\mathrm{Ba} 3$ & $\begin{array}{l}\text { Senior, Se- } \\
\text { cured \& } \\
\text { Asset } \\
\text { Backed }\end{array}$ \\
\hline CHINA & $\begin{array}{l}\text { Guangzhou- } \\
\text { Shenzhen Super- } \\
\text { highway (Hold- } \\
\text { ings) Ltd. }\end{array}$ & $\begin{array}{l}\text { Trans- } \\
\text { port }\end{array}$ & $\begin{array}{l}\text { 11-Aug- } \\
97\end{array}$ & 7.00 & 200.00 & 375 & 313 & $\mathrm{Ba} 3$ & $\begin{array}{l}\text { Senior, Un- } \\
\text { secured }\end{array}$ \\
\hline CHINA & $\begin{array}{l}\text { Guangzhou- } \\
\text { Shenzhen Super- } \\
\text { highway (Hold- } \\
\text { ings) Ltd }\end{array}$ & $\begin{array}{l}\text { Trans- } \\
\text { port }\end{array}$ & $\begin{array}{l}\text { 11-Aug- } \\
97\end{array}$ & 10.00 & 400.00 & 412.5 & 313 & $\mathrm{Ba} 3$ & $\begin{array}{l}\text { Senior, Un- } \\
\text { secured }\end{array}$ \\
\hline
\end{tabular}




\begin{tabular}{|c|c|c|c|c|c|c|c|c|c|}
\hline Country & Project & Sector & $\begin{array}{l}\text { Issue } \\
\text { Date }\end{array}$ & $\begin{array}{c}\text { Ma- } \\
\text { turity }\end{array}$ & $\begin{array}{c}\text { Amoun } \\
t\end{array}$ & $\begin{array}{l}\text { At- } \\
\text { issue } \\
\text { Sprea } \\
\text { d } \\
\end{array}$ & $\begin{array}{l}\text { Host- } \\
\text { Coun- } \\
\text { try } \\
\text { Spread } \\
\end{array}$ & Ratings & Structure \\
\hline CHINA & $\begin{array}{l}\text { Huaneng Power } \\
\text { International Inc. }\end{array}$ & Energy & $\begin{array}{l}\text { 21-Nov- } \\
97\end{array}$ & 6.50 & 230.00 & 10 & 473 & BBB & $\begin{array}{l}\text { Senior, Un- } \\
\text { secured }\end{array}$ \\
\hline CHINA & $\begin{array}{l}\text { Suzhou Devel- } \\
\text { opment Trust }\end{array}$ & Other & 7-Oct-97 & 15.00 & 103.50 & $\begin{array}{c}237.74 \\
8\end{array}$ & 297 & $\mathrm{Ba} 3$ & $\begin{array}{l}\text { Pari-Passu, } \\
\text { Asset } \\
\text { Backed } \\
\text { Guaranteed }\end{array}$ \\
\hline CHINA & $\begin{array}{l}\text { Zhuhai Highway } \\
\text { Co. }\end{array}$ & $\begin{array}{c}\text { Trans- } \\
\text { port }\end{array}$ & 7-Aug-96 & 10.00 & 85.00 & 250 & 655 & Baa3 & $\begin{array}{l}\text { Senior, Un- } \\
\text { secured }\end{array}$ \\
\hline CHNA & $\begin{array}{l}\text { Zhuhai Highway } \\
\text { Co. }\end{array}$ & $\begin{array}{l}\text { Trans- } \\
\text { port }\end{array}$ & 7-Aug-96 & 12.00 & 115.00 & 475 & 655 & Baa3 & $\begin{array}{l}\text { Senior, Un- } \\
\text { secured }\end{array}$ \\
\hline COLOMBIA & $\begin{array}{l}\text { Oil Purchase } \\
\text { Company II }\end{array}$ & Energy & $\begin{array}{c}\text { 11-May- } \\
99\end{array}$ & 5.00 & 175.60 & $\begin{array}{c}532.89 \\
6\end{array}$ & 698 & $\mathrm{Ba} 2$ & $\begin{array}{l}\text { Senior Se- } \\
\text { cured \& } \\
\text { Asset } \\
\text { Backed }\end{array}$ \\
\hline COLOMBIA & $\begin{array}{l}\text { Oleoducto Cen- } \\
\text { tral S.A. }\end{array}$ & $\begin{array}{l}\text { Trans- } \\
\text { mission }\end{array}$ & 28-Jun-95 & 10.00 & 150.00 & $\begin{array}{c}324.62 \\
4\end{array}$ & 1109 & Baa3 & $\begin{array}{l}\text { Senior Se- } \\
\text { cured \& } \\
\text { Guaranteed }\end{array}$ \\
\hline COLOMBIA & $\begin{array}{l}\text { TermoEmcali } \\
\text { Funding Corp. }\end{array}$ & Power & 16-Apr-97 & 17.68 & 165.00 & $\begin{array}{c}300.01 \\
3\end{array}$ & 435 & & $\begin{array}{l}\text { Senior, Se- } \\
\text { cured }\end{array}$ \\
\hline COLOMBIA & $\begin{array}{l}\text { TransGas de } \\
\text { Occidente S.A. }\end{array}$ & $\begin{array}{c}\text { Trans- } \\
\text { mission }\end{array}$ & $\begin{array}{l}\text { 10-Nov- } \\
95\end{array}$ & 15.00 & 240.00 & $\begin{array}{c}359.42 \\
9\end{array}$ & 1187 & Baa3 & $\begin{array}{l}\text { Senior, Se- } \\
\text { cured }\end{array}$ \\
\hline COLOMBIA & Transtel & Telecom & 28-Oct-97 & 10.00 & 150.00 & $\begin{array}{c}651.94 \\
4\end{array}$ & 468 & B2 & $\begin{array}{l}\text { Senior, Se- } \\
\text { cured }\end{array}$ \\
\hline CZECH REP. & Aero Vodochody & Other & $\begin{array}{l}\text { 17-Nov- } \\
98\end{array}$ & 7.00 & 200.00 & 280 & 920 & Baal & $\begin{array}{l}\text { Senior, Un- } \\
\text { secured \& } \\
\text { Asset } \\
\text { Backed } \\
\text { Guaranteed }\end{array}$ \\
\hline CZECH REP. & CEZ Finance BV & Power & 22-Jul-97 & 10.00 & 200.00 & 95 & 340 & Baal & $\begin{array}{l}\text { Senior, Un- } \\
\text { secured \& } \\
\text { Asset } \\
\text { Backed }\end{array}$ \\
\hline $\begin{array}{l}\text { DOMINICAN } \\
\text { REP. }\end{array}$ & Tricom & Telecom & $\begin{array}{l}\text { 21-Aug- } \\
97\end{array}$ & 7.00 & 200.00 & 510 & 314 & B2 & $\begin{array}{l}\text { Senior, Un- } \\
\text { secured \& } \\
\text { Asset } \\
\text { Backed }\end{array}$ \\
\hline HONG KONG & $\begin{array}{l}\text { Kowloon Canton } \\
\text { Railway Corp. }\end{array}$ & $\begin{array}{c}\text { Trans- } \\
\text { port }\end{array}$ & $\begin{array}{l}\text { 16-Mar- } \\
00\end{array}$ & 10.00 & 1000.00 & 168 & 530 & $\mathrm{~A} 3$ & $\begin{array}{l}\text { Senior, Un- } \\
\text { secured }\end{array}$ \\
\hline HONG KONG & $\begin{array}{l}\text { New World In- } \\
\text { frastructure Lim- } \\
\text { ited }\end{array}$ & Other & $\begin{array}{l}\text { 24-Mar- } \\
\quad 98\end{array}$ & 5.00 & 300.00 & 173 & 434 & $\mathrm{Ba} 3$ & $\begin{array}{l}\text { Senior, Un- } \\
\text { secured }\end{array}$ \\
\hline INDIA & $\begin{array}{l}\text { Tata Electric } \\
\text { Companies (The) }\end{array}$ & Power & $\begin{array}{l}\text { 12-Aug- } \\
97\end{array}$ & 10.00 & 150.00 & 160 & 309 & Baa3 & $\begin{array}{l}\text { Senior, Un- } \\
\text { secured }\end{array}$ \\
\hline INDLA & $\begin{array}{l}\text { Tata Electric } \\
\text { Companies (The) }\end{array}$ & Power & $\begin{array}{l}\text { 12-Aug- } \\
97\end{array}$ & 20.00 & 150.00 & 193 & 309 & Baa3 & $\begin{array}{l}\text { Senior, Un- } \\
\text { secured }\end{array}$ \\
\hline INDONESIA & $\begin{array}{l}\text { DSPL Finance } \\
\text { Company B.V. }\end{array}$ & & $\begin{array}{l}\text { 28-Aug- } \\
96\end{array}$ & 14.35 & 150.00 & $\begin{array}{c}219.32 \\
6\end{array}$ & 617 & $\mathrm{Baa} 3$ & $\begin{array}{l}\text { Senior, Se- } \\
\text { cured \& } \\
\text { Asset } \\
\text { Backed } \\
\text { Guaranteed }\end{array}$ \\
\hline
\end{tabular}




\begin{tabular}{|c|c|c|c|c|c|c|c|c|c|}
\hline Country & Project & Sector & $\begin{array}{l}\text { Issue } \\
\text { Date }\end{array}$ & $\begin{array}{l}\text { Ma- } \\
\text { turity }\end{array}$ & $\underset{t}{\text { Amoun }}$ & $\begin{array}{c}\text { At- } \\
\text { issue } \\
\text { Sprea } \\
\text { d }\end{array}$ & $\begin{array}{c}\text { Host- } \\
\text { Coun- } \\
\text { try } \\
\text { Spread }\end{array}$ & Ratings & Structure \\
\hline KOREA & $\begin{array}{l}\text { Korea Electric } \\
\text { Power Corp. }\end{array}$ & Power & $\begin{array}{l}\text { 31-Mar- } \\
00\end{array}$ & 5.00 & 300.00 & 190 & 556 & $\mathrm{Ba} 1$ & $\begin{array}{l}\text { Senior, Un- } \\
\text { secured }\end{array}$ \\
\hline MALAYSIA & $\begin{array}{l}\text { Petroliam Na- } \\
\text { sional Berhard }\end{array}$ & Energy & 1-Jul-93 & 10.00 & 500.00 & 98 & 405 & A2 & $\begin{array}{l}\text { Senior, Un- } \\
\text { secured }\end{array}$ \\
\hline MALAYSIA & $\begin{array}{l}\text { Petroliam Na- } \\
\text { sional Berhard }\end{array}$ & Energy & $\begin{array}{l}\text { 17-Aug- } \\
95\end{array}$ & 10.00 & 375.00 & 69 & 1056 & Al & $\begin{array}{l}\text { Senior, Un- } \\
\text { secured }\end{array}$ \\
\hline MALAYSIA & $\begin{array}{l}\text { Petroliam Na- } \\
\text { sional Berhard }\end{array}$ & Energy & $\begin{array}{l}\text { 17-Aug- } \\
95\end{array}$ & 20.00 & 625.00 & 86 & 1056 & A1 & $\begin{array}{l}\text { Senior, Un- } \\
\text { secured }\end{array}$ \\
\hline MALAYSIA & $\begin{array}{l}\text { Petroliam Na- } \\
\text { sional Berhard }\end{array}$ & Energy & $18-$ Oct-96 & 10.00 & 800.00 & 57 & 536 & A1 & $\begin{array}{l}\text { Senior, Un- } \\
\text { secured }\end{array}$ \\
\hline MALAYSIA & $\begin{array}{l}\text { Petroliam Na- } \\
\text { sional Berhard }\end{array}$ & Energy & $\begin{array}{l}\text { 12-Aug- } \\
99\end{array}$ & 5.00 & 650.00 & 320 & 844 & Baa3 & $\begin{array}{l}\text { Senior, Un- } \\
\text { secured }\end{array}$ \\
\hline MALAYSIA & $\begin{array}{l}\text { Telekom Malay- } \\
\text { sia }\end{array}$ & Telecom & $\begin{array}{l}\text { 10-Aug- } \\
95\end{array}$ & 10.00 & 200.00 & 72 & 1022 & A1 & $\begin{array}{l}\text { Senior, Un- } \\
\text { secured }\end{array}$ \\
\hline MALAYSIA & $\begin{array}{l}\text { Telekom Malay- } \\
\text { sia }\end{array}$ & Telecom & 3-Aug-95 & 10.00 & 300.00 & 102 & 1071 & Al & $\begin{array}{l}\text { Senior, Un- } \\
\text { secured }\end{array}$ \\
\hline MALAYSIA & $\begin{array}{l}\text { Tenaga Nasional } \\
\text { Berhad }\end{array}$ & Power & 22-Jun-94 & 10.00 & 600.00 & 89 & 874 & A2 & $\begin{array}{l}\text { Senior, Un- } \\
\text { secured }\end{array}$ \\
\hline MALAYSIA & $\begin{array}{l}\text { Tenaga Nasional } \\
\text { Berhad }\end{array}$ & Power & $31-$ Oct-95 & 30.00 & 350.00 & $\begin{array}{c}121.90 \\
6\end{array}$ & 1124 & Al & $\begin{array}{l}\text { Senior, Un- } \\
\text { secured }\end{array}$ \\
\hline MALAYSIA & $\begin{array}{l}\text { Tenaga Nasional } \\
\text { Berhad }\end{array}$ & Power & 16-Jan-96 & $\begin{array}{c}100.0 \\
0\end{array}$ & 150.00 & $\begin{array}{c}155.40 \\
6\end{array}$ & 866 & $\mathrm{~A} 1$ & $\begin{array}{l}\text { Senior, Un- } \\
\text { secured }\end{array}$ \\
\hline MALAYSIA & $\begin{array}{l}\text { Tenaga Nasional } \\
\text { Berhad }\end{array}$ & Power & 29-Apr-97 & 10.00 & 300.00 & 42 & 407 & Al & $\begin{array}{l}\text { Senior, Un- } \\
\text { secured }\end{array}$ \\
\hline MALAYSIA & $\begin{array}{l}\text { Tenaga Nasional } \\
\text { Berhad }\end{array}$ & Power & 29-Apr-97 & 10.00 & 500.00 & 73 & 407 & $\mathrm{Al}$ & $\begin{array}{l}\text { Senior, Un- } \\
\text { secured }\end{array}$ \\
\hline MALAYSIA & $\begin{array}{l}\text { Tenaga Nasional } \\
\text { Berhad }\end{array}$ & Power & 4-Apr-01 & 10.00 & 600.00 & 295 & 753 & $\mathrm{Baa} 3$ & $\begin{array}{l}\text { Senior, Un- } \\
\text { secured }\end{array}$ \\
\hline MEXICO & $\begin{array}{l}\text { Conproca S.A. } \\
\text { De C.V }\end{array}$ & Energy & 30-Jun-98 & 12.00 & 370.30 & 653 & 598 & $\mathrm{Ba} 2$ & $\begin{array}{l}\text { Senior, Se- } \\
\text { cured \& } \\
\text { Asset } \\
\text { Backed }\end{array}$ \\
\hline MEXICO & $\begin{array}{l}\text { El Habal Fun- } \\
\text { ding Trust }\end{array}$ & Power & 17-Jun-98 & 13.00 & 60.00 & $\begin{array}{c}471.95 \\
6\end{array}$ & 540 & $\mathrm{Ba} 2$ & $\begin{array}{l}\text { Senior, Se- } \\
\text { cured \& } \\
\text { Asset } \\
\text { Backed }\end{array}$ \\
\hline MEXICO & $\begin{array}{l}\text { Fideicomiso Pe- } \\
\text { tacalco }\end{array}$ & Power & 23-Apr-97 & 13.00 & 308.90 & 325 & 421 & $\mathrm{Ba} 2$ & $\begin{array}{l}\text { Senior, Se- } \\
\text { cured \& } \\
\text { Asset } \\
\text { Backed } \\
\text { Guaranteed }\end{array}$ \\
\hline MEXICO & $\begin{array}{l}\text { Monterrey Po- } \\
\text { wer, S.A. de } \\
\text { C.V. }\end{array}$ & Power & 24-Apr-98 & 11.57 & 235.54 & 400 & 445 & $\mathrm{Ba} 2$ & $\begin{array}{l}\text { Senior, Se- } \\
\text { cured \& } \\
\text { Asset } \\
\text { Backed }\end{array}$ \\
\hline MEXICO & Pemex Finance & Energy & 14-Dec-98 & 20.00 & 250.00 & 412.5 & 1027 & Baal & $\begin{array}{l}\text { Pari-Passu } \\
\text { Asset } \\
\text { Backed }\end{array}$ \\
\hline
\end{tabular}




\begin{tabular}{|c|c|c|c|c|c|c|c|c|c|}
\hline Country & Project & Sector & $\begin{array}{l}\text { Issue } \\
\text { Date } \\
\end{array}$ & $\begin{array}{c}\text { Ma- } \\
\text { turity }\end{array}$ & $\begin{array}{c}\text { Amoun } \\
t\end{array}$ & $\begin{array}{c}\text { At- } \\
\text { issue } \\
\text { Sprea } \\
\text { d } \\
\end{array}$ & $\begin{array}{c}\text { Host- } \\
\text { Coun- } \\
\text { try } \\
\text { Spread }\end{array}$ & Ratings & Structure \\
\hline MEXICO & Pemex Finance & & 14-Dec-98 & 8.42 & 350.00 & 350 & 1027 & Baal & $\begin{array}{l}\text { Pari-Passu } \\
\text { Asset }\end{array}$ \\
\hline MEXICO & Pemex Finance & Energy & 25-Feb-99 & 8.00 & 200.00 & 362.5 & 961 & Baal & $\begin{array}{l}\text { Backed } \\
\text { Pari-Passu } \\
\text { Asset }\end{array}$ \\
\hline MEXICO & Pemex Finance & Energy & 25-Feb-99 & 11.73 & 200.00 & 400 & 961 & Baal & $\begin{array}{l}\text { Backed } \\
\text { Pari-Passu } \\
\text { Asset } \\
\text { Backed }\end{array}$ \\
\hline MEXICO & Pemex Finance & Energy & 25-Feb-99 & 5.00 & 300.00 & 115 & 961 & Aaa & $\begin{array}{l}\text { Pari-Passu } \\
\text { Asset } \\
\text { Backed }\end{array}$ \\
\hline MEXICO & Pemex Finance & Energy & 27-Jul-99 & 5.00 & 50.00 & 380 & 838 & Baa 1 & $\begin{array}{l}\text { Pari-Passu, } \\
\text { Unsecured } \\
\text { \& Asset } \\
\text { Backed }\end{array}$ \\
\hline MEXICO & Pemex Finance & Energy & 27-Jul-99 & 18.00 & 200.00 & 475 & 838 & Baal & $\begin{array}{l}\text { Pari-Passu, } \\
\text { Unsecured } \\
\text { \& Asset } \\
\text { Backed }\end{array}$ \\
\hline MEXICO & Pemex Finance & Energy & 27-Jul-99 & 5.00 & 225.00 & 365 & 838 & Baal & $\begin{array}{l}\text { Pari-Passu, } \\
\text { Unsecured } \\
\text { \& Asset } \\
\text { Backed }\end{array}$ \\
\hline MEXICO & Pemex Finance & Energy & 27-Jul-99 & 13.00 & 250.00 & $\begin{array}{c}137.01 \\
9\end{array}$ & 838 & Aaa & $\begin{array}{l}\text { Pari-Passu, } \\
\text { Unsecured } \\
\text { \& Asset } \\
\text { Backed }\end{array}$ \\
\hline MEXICO & Pemex Finance & & 27-Jul-99 & 10.00 & 600.00 & 400 & 838 & Baal & $\begin{array}{l}\text { Pari-Passu, } \\
\text { Unsecured } \\
\text { \& Asset }\end{array}$ \\
\hline MEXICO & Pemex Finance & $\begin{array}{l}\text { Energy } \\
\text { Energy }\end{array}$ & $10-$ Feb-00 & 13.00 & 150.00 & 150 & 532 & Aaa & $\begin{array}{l}\text { Backed } \\
\text { Senior, As- } \\
\text { set Backed }\end{array}$ \\
\hline MEXICO & Pemex Finance & Energy & $10-F e b-00$ & 11.00 & 800.00 & 275 & 532 & Baal & $\begin{array}{l}\text { Senior, As- } \\
\text { set Backed }\end{array}$ \\
\hline MEXICO & Pemex Finance & Energy & 12-Feb-01 & 7.00 & 1000.00 & 360 & 674 & Baa 1 & $\begin{array}{l}\text { Senior, Un- } \\
\text { secured As- } \\
\text { set Backed }\end{array}$ \\
\hline MEXICO & $\begin{array}{l}\text { Pemopro S.A. de } \\
\text { C.V. }\end{array}$ & Energy & 26-Oct-99 & 3.35 & 161.00 & 455.25 & 708 & $\mathrm{Ba} 1$ & $\begin{array}{l}\text { Senior, Se- } \\
\text { cured Gu- } \\
\text { ranteed }\end{array}$ \\
\hline MEXICO & $\begin{array}{l}\text { Proyectos de } \\
\text { Energia, S.A. de } \\
\text { C.V. }\end{array}$ & & $\begin{array}{c}\text { 14-May- } \\
98\end{array}$ & 5.00 & 100.00 & $\begin{array}{c}405.41 \\
9\end{array}$ & 479 & $\mathrm{Ba} 2$ & $\begin{array}{l}\text { Senior, Se- } \\
\text { cured \& } \\
\text { Asset }\end{array}$ \\
\hline PANAMA & $\begin{array}{l}\text { PYCSA Panama } \\
\text { S.A. }\end{array}$ & $\begin{array}{l}\text { Power } \\
\text { Trans- } \\
\text { port }\end{array}$ & $6-$ Oct-97 & 15.00 & 131.00 & 425 & 299 & $\mathrm{Ba} 3$ & $\begin{array}{l}\text { Backed } \\
\text { Senior, Un- } \\
\text { secured }\end{array}$ \\
\hline
\end{tabular}




\begin{tabular}{|c|c|c|c|c|c|c|c|c|c|}
\hline Country & Project & Sector & $\begin{array}{l}\text { Issue } \\
\text { Date }\end{array}$ & $\begin{array}{c}\text { Ma- } \\
\text { turity }\end{array}$ & $\begin{array}{c}\text { Amoun } \\
t\end{array}$ & $\begin{array}{c}\text { At- } \\
\text { issue } \\
\text { Sprea } \\
\text { d } \\
\end{array}$ & $\begin{array}{c}\text { Host- } \\
\text { Coun- } \\
\text { try } \\
\text { Spread }\end{array}$ & Ratings & Structure \\
\hline PHILIPPINES & $\begin{array}{l}\text { Bauang Private } \\
\text { Power Corp. }\end{array}$ & Power & $\begin{array}{l}\text { 28-Mar- } \\
96\end{array}$ & 12.00 & 85.00 & $\begin{array}{c}366.14 \\
3\end{array}$ & 850 & $\mathrm{Ba} 2$ & $\begin{array}{l}\text { Senior, Se- } \\
\text { cured \& } \\
\text { Asset } \\
\text { Backed } \\
\text { Guaranteed }\end{array}$ \\
\hline PHILIPPINES & $\begin{array}{l}\text { CE Casecnan } \\
\text { Water and En- } \\
\text { ergy Co. Inc. }\end{array}$ & $\begin{array}{l}\text { Wa- } \\
\text { ter\&Ener } \\
\text { gy }\end{array}$ & $\begin{array}{l}\text { 21-Nov- } \\
95\end{array}$ & 7.00 & 75.00 & $\begin{array}{c}337.10 \\
9\end{array}$ & 1140 & $\mathrm{Ba} 2$ & $\begin{array}{l}\text { Senior, Se- } \\
\text { cured \& } \\
\text { Asset } \\
\text { Backed }\end{array}$ \\
\hline PHILIPPINES & $\begin{array}{l}\text { CE Casecnan } \\
\text { Water and En- } \\
\text { ergy Co. Inc. }\end{array}$ & $\begin{array}{l}\text { Wa- } \\
\text { ter\&Ener } \\
\text { gy }\end{array}$ & $\begin{array}{l}\text { 27-Nov- } \\
95\end{array}$ & 10.00 & 125.00 & $\begin{array}{c}556.83 \\
2\end{array}$ & 1125 & $\mathrm{Ba} 2$ & $\begin{array}{l}\text { Senior, Se- } \\
\text { cured \& } \\
\text { Asset } \\
\text { Backed }\end{array}$ \\
\hline PHILIPPINES & $\begin{array}{l}\text { CE Casecnan } \\
\text { Water and En- } \\
\text { ergy Co. Inc. }\end{array}$ & $\begin{array}{l}\text { Wa- } \\
\text { ter\&Ener } \\
\text { gy }\end{array}$ & $\begin{array}{c}\text { 27-Nov- } \\
95\end{array}$ & 15.00 & 171.50 & $\begin{array}{c}585.34 \\
5\end{array}$ & 1125 & $\mathrm{Ba} 2$ & $\begin{array}{l}\text { Senior, Se- } \\
\text { cured \& } \\
\text { Asset } \\
\text { Backed }\end{array}$ \\
\hline PHILIPPINES & Globe Telecom & Telecom & $\begin{array}{l}\text { 27-Mar- } \\
02\end{array}$ & 10.00 & 200.00 & 442 & 487 & $\mathrm{Ba} 3$ & $\begin{array}{l}\text { Senior, Un- } \\
\text { secured }\end{array}$ \\
\hline PHILIPPINES & Globe Telecom & Telecom & 6-Aug-99 & 10.00 & 220.00 & 709 & 872 & B1 & $\begin{array}{l}\text { Senior, Un- } \\
\text { secured }\end{array}$ \\
\hline PHILIPPINES & $\begin{array}{l}\text { National Power } \\
\text { Corp. }\end{array}$ & Power & 13-Dec-96 & 10.00 & 200.00 & 167 & 492 & $\mathrm{Ba} 2$ & $\begin{array}{l}\text { Senior, Un- } \\
\text { secured \& } \\
\text { Asset } \\
\text { Backed }\end{array}$ \\
\hline PHILIPPINES & $\begin{array}{l}\text { National Power } \\
\text { Corp. }\end{array}$ & Power & 13-Dec-96 & 20.00 & 160.00 & 190 & 492 & $\mathrm{Ba} 2$ & $\begin{array}{l}\text { Senior, Un- } \\
\text { secured \& } \\
\text { Asset } \\
\text { Backed }\end{array}$ \\
\hline PHILIPPINES & $\begin{array}{l}\text { National Power } \\
\text { Corp. }\end{array}$ & Power & 6-May-98 & 30.00 & 300.00 & 386.5 & 460 & $\mathrm{Ba} 1$ & $\begin{array}{l}\text { Senior, Un- } \\
\text { secured \& } \\
\text { Asset } \\
\text { Backed }\end{array}$ \\
\hline PHILIPPINES & $\begin{array}{l}\text { Quezon Power } \\
\text { (Philippines) } \\
\text { Ltd. }\end{array}$ & Power & 3-Jul-97 & 10.00 & 215.00 & 245 & 330 & Bal & $\begin{array}{l}\text { Senior, Se- } \\
\text { cured }\end{array}$ \\
\hline QATAR & $\begin{array}{l}\text { Ras Laffan Liq- } \\
\text { uefied Natural } \\
\text { Gas Co. Ltd. }\end{array}$ & Energy & 12-Dec-96 & 10.00 & 400.00 & 137.5 & 498 & A3 & $\begin{array}{l}\text { Senior, Se- } \\
\text { cured }\end{array}$ \\
\hline QATAR & $\begin{array}{l}\text { Ras Laffan Liq- } \\
\text { uefied Natural } \\
\text { Gas Co. Ltd. }\end{array}$ & Energy & 12-Dec-96 & 18.00 & 800.00 & 187.5 & 498 & A3 & $\begin{array}{l}\text { Senior, Se- } \\
\text { cured }\end{array}$ \\
\hline RUSSIA & Mosenergo, AO & Power & 9-Oct-97 & 5.00 & 200.00 & 250 & 305 & BB- & $\begin{array}{l}\text { Senior, Un- } \\
\text { secured }\end{array}$ \\
\hline $\begin{array}{l}\text { SOUTH } \\
\text { AFRICA }\end{array}$ & Transnet Ltd. & $\begin{array}{c}\text { Trans- } \\
\text { port }\end{array}$ & 17-Apr-98 & 30.00 & 396.82 & $\begin{array}{c}802.17 \\
2\end{array}$ & 447 & Baal & $\begin{array}{l}\text { Senior, Un- } \\
\text { secured \& } \\
\text { Guaranteed }\end{array}$ \\
\hline
\end{tabular}




\begin{tabular}{|c|c|c|c|c|c|c|c|c|c|}
\hline Country & Project & Sector & $\begin{array}{l}\text { Issue } \\
\text { Date } \\
\end{array}$ & $\begin{array}{l}\text { Ma- } \\
\text { turity }\end{array}$ & $\begin{array}{c}\text { Amoun } \\
t\end{array}$ & $\begin{array}{l}\text { At- } \\
\text { issue } \\
\text { Sprea } \\
\text { d } \\
\end{array}$ & $\begin{array}{l}\text { Host- } \\
\text { Coun- } \\
\text { try } \\
\text { Spread } \\
\end{array}$ & Ratings & Structure \\
\hline THAILAND & EGAT & Power & 6-Oct-98 & 10.00 & 300.00 & 285 & 1196 & $\mathrm{~A} 3$ & $\begin{array}{l}\text { Senior, Un- } \\
\text { secured \& } \\
\text { Asset } \\
\text { Backed } \\
\text { Guaranteed }\end{array}$ \\
\hline THAILAND & $\begin{array}{l}\text { Jasmine Subma- } \\
\text { rine Telecom- } \\
\text { munications co. } \\
\text { Ltd }\end{array}$ & Telecom & $\begin{array}{l}\text { 29-May- } \\
97\end{array}$ & 14.00 & 180.00 & 175 & 354 & Baal & $\begin{array}{l}\text { Senior, Se- } \\
\text { cured \& } \\
\text { Asset } \\
\text { Backed }\end{array}$ \\
\hline THAILAND & $\begin{array}{l}\text { Total Access } \\
\text { Communications }\end{array}$ & Telecom & 4-Nov-96 & 10.00 & 300.00 & 200 & 519 & BB- & $\begin{array}{l}\text { Senior, Un- } \\
\text { secured }\end{array}$ \\
\hline VENEZUELA & $\begin{array}{l}\text { Cerro Negro } \\
\text { Finance Ltd. }\end{array}$ & Energy & 18-Jun-98 & 11.46 & 200.00 & 180 & 560 & Baal & $\begin{array}{l}\text { Senior, Se- } \\
\text { cured \& } \\
\text { Asset } \\
\text { Backed }\end{array}$ \\
\hline VENEZUELA & $\begin{array}{l}\text { Cerro Negro } \\
\text { Finance Ltd. }\end{array}$ & Energy & 18-Jun-98 & 22.47 & 350.00 & 225 & 560 & Baal & $\begin{array}{l}\text { Senior, Se- } \\
\text { cured \& } \\
\text { Asset } \\
\text { Backed }\end{array}$ \\
\hline VENEZUELA & $\begin{array}{l}\text { Cerro Negro } \\
\text { Finance Ltd. }\end{array}$ & Energy & 18-Jun-98 & 30.00 & 50.00 & 237.5 & 560 & Baa1 & $\begin{array}{l}\text { Senior, Se- } \\
\text { cured \& } \\
\text { Asset } \\
\text { Backed } \\
\text { Guaranteed }\end{array}$ \\
\hline VENEZUELA & $\begin{array}{l}\text { Fertinitro Finan- } \\
\text { ce Inc. }\end{array}$ & & 21-Apr-98 & 22.00 & 250.00 & $\begin{array}{c}227.31 \\
7\end{array}$ & 442 & Baa3 & $\begin{array}{l}\text { Senior, Se- } \\
\text { cured }\end{array}$ \\
\hline VENEZUELA & $\begin{array}{l}\text { Petrozuata Fi- } \\
\text { nance Inc. or } \\
\text { Petrolera Zuata }\end{array}$ & Energy & 27-Jun-97 & 12.00 & 300.00 & 120 & 344 & Baal & $\begin{array}{l}\text { Senior, Se- } \\
\text { cured \& } \\
\text { Asset } \\
\text { Backed } \\
\text { Guaranteed }\end{array}$ \\
\hline VENEZUELA & $\begin{array}{l}\text { Petrozuata Fi- } \\
\text { nance Inc. or } \\
\text { Petrolera Zuata }\end{array}$ & Energy & 27-Jun-97 & 20.00 & 625.00 & 145 & 344 & Baal & $\begin{array}{l}\text { Senior, Se- } \\
\text { cured \& } \\
\text { Asset } \\
\text { Backed }\end{array}$ \\
\hline VENEZUELA & $\begin{array}{l}\text { Petrozuata Fi- } \\
\text { nance Inc. or } \\
\text { Petrolera Zuata }\end{array}$ & Energy & 27-Jun-97 & 25.00 & 75.00 & 160 & 344 & Baal & $\begin{array}{l}\text { Senior, Se- } \\
\text { cured \& } \\
\text { Asset } \\
\text { Backed }\end{array}$ \\
\hline
\end{tabular}


. 


Policy Research Working Paper Series

Title

WPS3071 Survey Techniques to Measure and Explain Corruption

WPS3072 Diversity Matters: The Economic Geography of Industry Location in India

WPS3073 Metropolitan Industrial Clusters: Patterns and Processes

WPS3074 The Gender Impact of Pension Reform: A Cross-Country Analysis

WPS3075 Child Labor, Income Shocks, and Access to Credit

WPS3076 Trade Reform in Vietnam: Opportunities with Emerging Challenges

WPS3077 Do More Transparent Governments Govern Better?

WPS3078 Regional Integration in East Asia: Challenges and OpportunitiesPart I: History and Institutions

WPS3079 Regional Integration in East Asia: Challenges and OpportunitiesPart II: Trade, Finance, and Integration

WPS3080 Can Fiscal Rules Help Reduce Macroeconomic Volatility in the Latin America and Caribbean Region?

WPS3081 The Anatomy of a Multiple Crisis: Why was Argentina Special and What Can We Learn from It?

WPS3082 Financial Dollarization and Central Bank Credibility

Guillermo Perry

Guillermo Perry

Luis Servén

Kevin Cowan

Quy-Toan Do

Michael Haney

Maria Shkaratan

Community: Five Years after

Closure in Romania, Russia, and Ukraine

WPS3084 Major Trade Trends in East Asia: What are their Implications for Regional Cooperation and Growth?

WPS3085 Export Profiles of Small Landlocked Countries: A Case Study Focusing on their Implications for Lesotho

Francis $\mathrm{Ng}$ Alexander Yeats

Francis $\mathrm{Ng}$

Alexander Yeats

Derek Hung Chiat Chen

WPS3086 Intertemporal Excess Burden, Bequest Motives, and the Budget Deficit

Contact

Date

for paper

June 2003

June 2003

June 2003

June 2003

June 2003

June 2003

June 2003

June 2003

June 2003

June 2003

June 2003

June 2003

June 2003

June 2003

June 2003

June 2003
H. Sladovich

37698

V. Soukhanov 35721

V. Soukanov 35721

$M$. Ponglumjeak 31060

E. de Castro 89121

K. Tomlinson 39763

R. Islam 32628

S. Yusuf 82339

S. Yusuf 82339

R. Izquierdo 84161

R. Izquierdo 84161

Q. Do 34813

L. Marquez 36578

P. Flewitt 32724

P. Flewitt 32724

D. Chen 81602 


\section{Policy Research Working Paper Series}

Title

WPS3087 Gender, Generations, and Nonfarm Participation

WPS3088 U.S. Contingent Protection against Honey Imports: Development Aspects and the Doha Round

WPS3089 The "Glass of Milk" Subsidy Program and Malnutrition in Peru

David Stifel

Harold Alderman

WPS3090 The Cotonou Agreement and its Implications for the Regional Trade Agenda in Eastern and Southern Africa

WPS3091 Labor Market Policies and Unemployment in Morocco: A Quantitative Analysis

Manuel de la Rocha

Pierre-Richard Agénor Karim El Aynaoui

M. Shahe Emran

Misuzu Otsuka

Forhad Shilpi

Julio J. Nogués

-Richard Agén Alejandro Izquierdo Hippolyte Fofack for Poverty Analysis: A Quantitative Macroeconomic Framework for the Analysis of Poverty Reduction Strategies

WPS3093 Migration and Human Capital in Brazil during the 1990s

Norbert M. Fiess Dorte Verner

Norbert M. Fiess

WPS3094 Oil, Agriculture, and the Public Sector: Linking Intersector Dynamics in Ecuador une 2003

June 2003

June 2003

July 2003

July 2003

Contact for paper

P. Kokila 33716

P. Flewitt 32724

H. Sladovich 37698

F. Sy 89750

M. Gosiengfiao 33363

M. Gosiengfiao 33363

July 2003

R. Izquierdo 84161

July 2003

R. Izquierdo 84161 